\title{
HIGH-RESOLUTION ACOUSTIC MAPPING OF GAS CHARGED SEDIMENTS AND LIVING BENTHIC FORAMINIFERA ASSEMBLAGES FROM THE NE REGION OF THE GUANABARA BAY (RJ, BRAZIL)
}

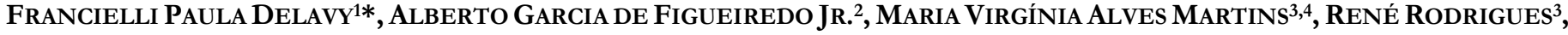 \\ Egberto Pereira ${ }^{3}$, Marco António Ruivo de Castro e Brito ${ }^{3}$, Maria Clara Machado da Fonseca ${ }^{5}$, Lazaro Luiz

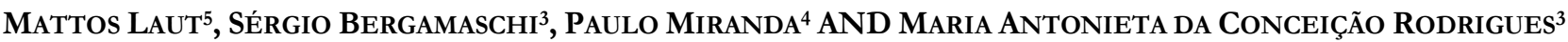

1 Programa de Capacitação Institucional, Museu Paraense Emílio Goeldi, Coordenação de Botânica. Av. Perimetral, Terra Firme, CEP 66077830, Belém, PA, Brazil. delavy7@gmail.com

2 Universidade Federal Fluminense, Departamento de Geologia, Lagemar. Av. Milton Tavares de Souza, s/n, CEP 24210-340, Niterói, RJ, Brazil. afigueiredo@id.uff.br

3 Universidade do Estado do Rio de Janeiro - UERJ, Faculdade de Geologia, Departamento de Estratigrafia e Paleontologia. Av. São Francisco Xavier, 524, sala 2020A, Maracanã. CEP 20550-013 Rio de Janeiro, Brazil. virginia.martins@ua.pt, rene@uerj.br, egbertogeologia@gmail.com, castro.marco@hotmail.com, sergioberg7@hotmail.com, tutucauerj@gmail.com

4 Universidade de Aveiro, GeoBioTec, Departamento de Geociências, Campus de Santiago, $3810-193$ Aveiro, Portugal. pfnmiranda@gmail.com

5 Undergraduate student, Laboratory of Micropaleontology Universidade do Estado do Rio de Janeiro,LMP-UERJ, Faculdade de Geologia, Departamento de Estratigrafia e Paleontologia. Av. São Francisco Xavier, 524, sala 4031F, Maracanã, CEP 20550-013 Rio de Janeiro, Brazil.geomariaclara@gmail.com

6 Universidade Federal do Estado do Rio de Janeiro - UNIRIO, Laboratório de Micropaleontologia - LabMicro, Av. Pasteur, 458, IBIO/CCET sala 500 Urca, CEP 22.240-490, Rio de Janeiro, Brazil. lazarolaut@hotmail.com

*Corresponding AUTHOR, delavy7@gmail.com

Received in 13 April 2016

Received in revised form in 28 October2016

Accepted in 30 October2016

Editor: Fabrizio Frontalini, Università degli Studi di Urbino "Carlo Bo", Dipartimento di Scienze Pure e Applicate (DiSPeA), Urbino, Italy
Citation:

Delavy, F.P., Figueiredo Jr., A.G., Martins, M.V.A., Rodrigues, R., Pereira, E., Brito, M.A.R.C., Fonseca, M.C.M., Laut, L.L.M., Bergamaschi, S., Miranda, P., Rodrigues, M.A.C., 2016. High-resolution acoustic mapping of gas charged sediments and living benthic foraminifera assemblages from the NE region of the Guanabara Bay (RJ, Brazil). Journal of Sedimentary Environments, 1 (3): 360384 .

\begin{abstract}
This work was performed in the NE region of the Guanabara Bay, a highly impacted Brazilian coastal system, located in Rio de Janeiro State. It aimed to: i) identify and map the areas with occurrence of gas in the sediment, as well as its acoustic signature; ii) characterize the physical properties of the sediments and; iii) document the response of microbenthic organisms (living benthic foraminifera) to changes in quantity and quality of organic matter. Seismic surveys at the frequency of $12 \mathrm{kHz}$ identified a large area with about $50 \%$ gas charged sediments in the study area.
\end{abstract}

The main acoustic signatures of the shallow gas were black shadow and gas blanket. In addition, features related to gas seepages to the water column (acoustic plumes and pockmarks) and gas percolation within the sediments (intra- sedimentary plumes, turbidity pinnacles) were also identified. The gas has a biogenic origin and results from the high acumulation rate between 0.03 to $0.9 \mathrm{~cm}$.year ${ }^{-1}$ and from the decomposition of large amount of organic matter (10-20\%). Vertical distribution of gas ranges from few centimeters to 9 $\mathrm{m}$ below the water-sediments interface. These occurrences are related to both gas migration from lower sedimentary layers to Holocene muds above, and to recent generation in near-surface sediments as the area display favorable conditions for gas production. Cores ranging from 150-240 $\mathrm{cm}$ in length have predominantly muddy sediments and variations in the $\mathrm{P}$-wave velocity followed the changes in sediment density, controlled mainly by the presence of gas in sediments, bioclasts accumulation, textural variation and percentage of organic matter. 
The TOC content and Rock-Eval pyrolysis parameters evaluated in nine surface sediment samples indicate that good to excellent amount of organic matter associated with moderate to good source potential for gas production is present in the study area. In these areas living benthic foraminifera are of reduced diversity and density. The assemblages are largely dominated by Ammonia tepida. Statistical results evidence that areas of intense gas release

\section{Introduction}

Gas bearing sediments are a globally phenomenon observed from coastal areas to the deep ocean but are quite common in shallow environments with a depth of less than $50 \mathrm{~m}$ (Judd, 2004, Vardar and Alpar, 2016). The shallow gas accumulation in the first kilometer of sediment may have biogenic or thermogenic origin (Iglesias and García-Gil, 2007; Wessels, et al., 2010).

Thermogenic hydrocarbon gasses are found in the sediment at depths where organic matter encounters high temperatures and pressure, i.e., several hundreds of meters to kilometers below the Earth's surface (Schoell, 1988) and are produced by high temperature degradation and cracking of organic compounds at considerable burial depths (Judd et al., 1997; Missiaen et al., 2002). On the other hand, the biogenic gas is formed at low temperatures by microbial methanogenesis that is the degradation of organisms such as planktonic matters, plants, fishes, and other organic material under anaerobic conditions (Kitidis et al., 2007).

The biogenic gas is isotopically depleted $\left(\delta^{13} \mathrm{C}<-60 \%\right.$ ), and has extremely high methane content (Santos Neto, 2004). Methane $\left(\mathrm{CH}_{4}\right)$ is the most common and abundant hydrocarbon gas in near-surface sediments (Judd et al., 2002). Most biogenic methane is produced by the anaerobic degradation of abundant organic matter and deposited in marine subsurface where the accumulation rate is high (Hovland and Judd, 1988).

Sediments with large quantities of organic matter, particularly with fine granulometry, are more prone to methane generation (Judd, 2004). Consequently, migration of gas or methane-rich interstitial water tends to occur by permeable migration paths (Yun et al., 1999).

Most of the shallow gas-bearing sediments, as well as gas escape features, are observed in bays, deltaic accumulations and in basins (Ivanov et al., 1998; Okyar and Ediger, 1999; Yun et al., 1999).

The gassy sediments can be easily identified by highresolution reflection seismic data (Vardar and Alpar, 2016). Depending on their seismic character, size and geometry, affect the benthic faunas since the benthic foraminiferal assemblages are reduced in diversity and density.

Keywords: Shallow gas. Physical properties. TOC. RockEval pyrolysis. Stable isotopes. Living benthic foraminifera.

various descriptive features have been used for gas charged sediments, such as acoustic blanket, black shadow, plumes, curtain, and acoustic turbidity (Taylor, 1992; Yun et al., 1999; Garcia-Gil et al., 2002; Baltzer et al., 2005).

The study of gas occurrences in sediment is important because in some cases the presence of gaseous hydrocarbons is a shallow signal of deeper and large accumulations in border basins (Okyar and Ediger, 1999). Methane is a strong greenhouse gas and is believed to contribute to rapid global climate changes depending on its concentration levels in the atmosphere (Overpeck and Cole 2006). Its global warming potential is more than 20 times higher compared to $\mathrm{CO}_{2}$ (Hovland and Judd, 1988; Hovland et al., 1993; Lowe and Walker, 1997; Judd et al., 2002).

The gas seeping can negatively affect the environment (Hovland and Judd, 1988; Hovland et al., 1993; Lowe and Walker 1997; Judd et al., 2002). However, the consequences of the gas seeping on the benthic communities of coastal ecosystems are yet poorly understood. In coastal areas, the gas escape occurs in eutrophic systems. Studies of the problems associated with eutrophication, pollution, contamination and its consequences on biodiversity, productivity of the marine ecosystem and sustainable development, seek the understanding of the physical, chemical and biological processes through indicators to prevent and tackle serious environmental problems.

Shallow water benthic foraminifera can be successfully used as proxies of environmental variables or as bioindicators of environmental status (Frontalini and Coccioni, 2008; Romano et al., 2009; Armynot du Châtelet et al., 2011; Foster et al., 2012; Schönfeld et al., 2012). They have several advantages in comparison to macrofaunal organisms (Schönfeld et al., 2012) like higher abundance and diversity, and shorter life and reproductive cycle. This means that much smaller sediment volumes are needed to obtain a high number of specimens essential to characterize the assemblages with statistical reliability. Foraminifera have in general short life cycles as compared to macrofaunal organisms and respond rapidly to environmental changes. 
They have a limited ability to move and their assemblages, therefore, reflect the conditions of the environment where they live.

\subsection{The main goals of this study}

Drawing upon the environmental, strategic and economic importance of the Guanabara Bay, this study aims to identify and map the areas with occurrence of gas in sediment, as well as its acoustic signature and the characterization of the physical properties of sediments. This work also intends to analyze how the microbenthic organisms (living benthic foraminifera) are affected by the enrichment of organic matter and gas escape in the NE region of the Guanabara Bay. To achieve this goal an integrated assessment including indicators of organic material content and quality using Rock-Eval pyrolysis parameters is applied. The results presented in this research can help in decision-making on dredging, remediation or engineering works, where proper procedures must be taken to reduce operational risks and environmental impacts.

Several works have been performed to study benthic foraminiferal distribution and ecology in the Guanabara Bay (Vilela et al., 2001 a, b, 2003, 2004, 2007, 2011; Fontana et al., 2006; Kfouri-Cardoso et al., 2006; Pereira et al., 2006; Figueira et al., 2007; Donnici et al., 2012; Eichler et al., 2013; Clemente et al., 2015) as well as in the sedimentary record to reconstruct paleoenvironmental evolution (e.g., Vilela et al., 2007; Baptista Neto et al., 2016). However, all the previous works in the Guanabara Bay have been based on total (living plus dead) benthic foraminiferal assemblages. Schönfeld et al. (2012) established as mandatory recommendation the use of living foraminifera to study the ecology of these organisms.

This work is as much as we know, the first one that uses living assemblages of benthic foraminifera in comparison of TOC content, Rock-Eval pyrolysis parameters, carbon stable isotope and sedimentological data obtained in cores and geophysical results to evaluate the influence of organic matter quantity and quality and gas releasing in the NE sector of the Guanabara Bay.

\subsection{Study area}

The Guanabara Bay is an estuarine system located in one of the most important urban areas of Brazil and presents different levels of natural and anthropogenic influence (Monteiro et al., 2012). On its margins are located the city of Rio de Janeiro and its metropolitan area including Niterói,
São Gonçalo, Magé, among other cities. Approximately 75\% of the population living in this great urban concentration directly discharges domestic effluents into the bay without any treatment.

The Guanabara Bay receives high loads of organic matter and pollutants and experiences a growing process of eutrophication (Amador, 1992; Baptista-Neto et al., 2000; Mendonça Filho et al., 2003; Catanzaro et al., 2004; Pereira et al., 2006). The hydrodynamic conditions in the Guanabara Bay are described and discussed by several authors that correlated them with the distribution of sediments (Amador, 1992; Quaresma, 1997; Baptista-Neto et al., 2000; Quaresma et al., 2000; Catanzaro et al., 2004).

Circulation and salinity are subject to the movements of ocean currents, tides, winds and river discharges (Kjerfve et al., 1997). The region of the Guanabara Bay connection with the sea is a very dynamic area, with strong currents in response to its asymmetrical geomorphology, in which there is a narrowing of its downstream portion and extending the upstream portion (JICA, 1994; Kjerfve et al., 1997, Guimarães et al., 2007). The bottom morphology inside the bay is also influenced by tidal currents that drain through the central channel carrying a large sediment load.

The accumulation of high amount of organic matter associated with the deposition of fine sediments has given rise to predominantly anaerobic metabolic processes (Silva et al., 2008), which has favored the formation of gas in surface and subsurface layers of sediment (Catanzaro, et al., 2004). The occurrence of seepages of gas bubbles into the water column by sediments is a well-known phenomenon that can be observed in large areas of the Guanabara Bay (Catanzaro et al., 2004).

\section{Material and methods}

\subsection{Geophysical data and gathering of cores}

Over $240 \mathrm{~km}$ of seismic lines were collected in the NE area of the Guanabara Bay (Brazil), (Fig. 1). These data were collected in the frequency of $12 \mathrm{kHz}$ with Bathy $2010 \mathrm{PC}^{\mathbf{T M}}$ of SyQwest using the hydrographic software HYPACK ${ }^{\circledR}$ 2013 for planning and navigation and GTR-G2 TechGeo DGPS for positioning.

The physical properties, compressional wave velocity (Vp), Gamma density, magnetic susceptibility and electrical resistivity were obtained by profiling four sedimentological cores in the Multi Sensor Core Logger, combined with visual description data. 

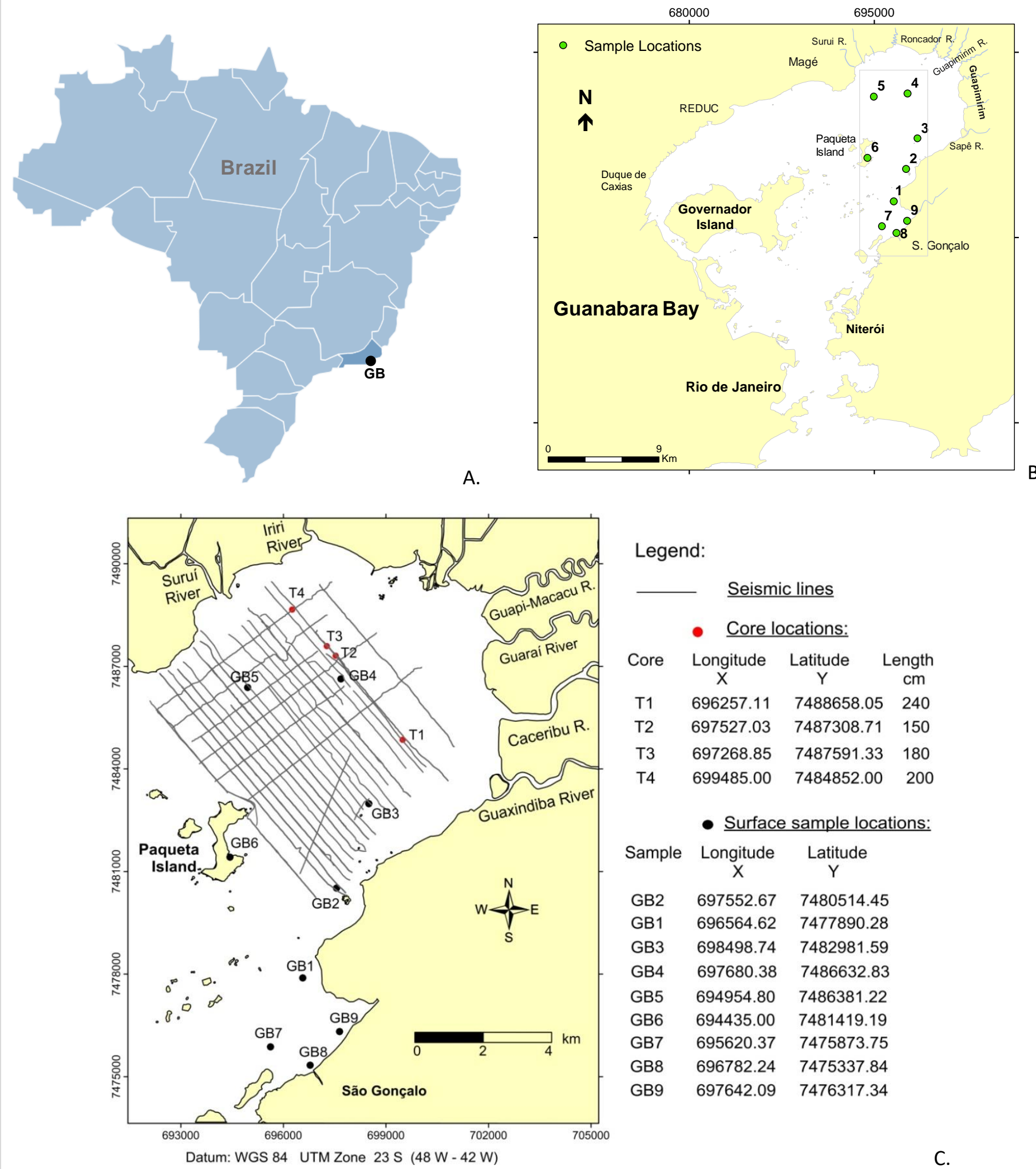

Legend:

\begin{tabular}{llll} 
& \multicolumn{3}{c}{ Seismic lines } \\
& $\bullet$ & \multicolumn{2}{c}{ Core locations: } \\
Core & Longitude & Latitude & Length \\
& X & Y & cm \\
T1 & 696257.11 & 7488658.05 & 240 \\
T2 & 697527.03 & 7487308.71 & 150 \\
T3 & 697268.85 & 7487591.33 & 180 \\
T4 & 699485.00 & 7484852.00 & 200
\end{tabular}

- Surface sample locations:

Sample Longitude Latitude

$\begin{array}{lll}\text { GB2 } & 697552.67 & 7480514.45 \\ \text { GB1 } & 696564.62 & 7477890.28 \\ \text { GB3 } & 698498.74 & 7482981.59 \\ \text { GB4 } & 697680.38 & 7486632.83 \\ \text { GB5 } & 694954.80 & 7486381.22 \\ \text { GB6 } & 694435.00 & 7481419.19 \\ \text { GB7 } & 695620.37 & 7475873.75 \\ \text { GB8 } & 696782.24 & 7475337.84 \\ \text { GB9 } & 697642.09 & 7476317.34\end{array}$

Fig. 1. A. Geographical location of the study area in Brazil (•). B. Studied stations for surface sediments in the NE region of the Guanabara Bay (GB1-9). C. The studied seismic lines, sediment cores (T1-T4) and the positions of surface sediment samples (GB1-9). 
Two sediment cores (T2 and T4) were collected in a zone with occurrence of gas in sediments and two others (T1 and T3) without the occurrence of gas in sediments (Fig. 1). Several data were acquired in these cores: grain size, organic matter (OM), carbonates, moisture content, geotechnical properties and radiocarbon data (Delavy, 2015).

\subsection{Sedimentological data obtained along the core}

Analysis of geotechnical properties, grain size, $\mathrm{OM}$ and carbonates were performed at $25-\mathrm{cm}$ resolution and moisture content at $4-\mathrm{cm}$ resolution along the cores. For geotechnical testing, a handheld penetrometer and Torvane shear device were used to estimate the sediments cohesion force and shear strength, respectively. The moisture content of the samples was obtained by the ratio between the weights of sediment with water and without water.

The concentrations of $\mathrm{OM}$ and carbonate were obtained applying a sediment calcination methodology (using $0.5 \mathrm{~g}$ of sediment) with the following steps: i) 1 hour at $100^{\circ} \mathrm{C}$ to obtain the dry sample weight; ii) 1 hour at $550^{\circ} \mathrm{C}$ to obtain organic matter content; and; iii) 1 hour at $1000^{\circ} \mathrm{C}$ to obtain carbonate content.

The grain size of core sediment was estimated using a laser granulometer model Malvern Mastersizer 2000. The data treatment was performed according to the statistical parameters of Folk and Ward (1957) through Gradistat software.

The ${ }^{14} \mathrm{C}$ analyses were performed by Accelerator Mass Spectrometry- AMS at the Radiocarbon Laboratory (LAC-
UFF). Calibration was performed with OxCal software (Bronk Ramsey, 2009) using the Marine13 calibration curve (Reimer et al., 2013) with an offset of $8 \pm 17$ years (Angulo et al., 2005).

\subsection{Sampling surface sediments}

Nine stations were sampled for surface sediment in the $\mathrm{NE}$ area of the Guanabara Bay, from the Paquetá Island to the inner zone of the bay on 27.01.2016 (Fig. 1; Tab. 1). Each sampled station was georeferenced with a GPS (model GPSMAP ${ }^{\circledR} 78$ S). The physicochemical data such as salinity, temperature, dissolved oxygen and $\mathrm{pH}$ were obtained with a multiparameteric probe. The sediment samples were collected with a box core.

Triplicates of samples were collected in each site according to the methodology established by Schönfeld et al. (2012). The first upper centimeter of sediment was scraped with a plastic spatula and placed in referenced plastic bags and containers to get sedimentological and biotic data (foraminifera).

During the fieldwork, the sediments for foraminiferal studies were stored in ethanol with Rose Bengal (2 $\mathrm{g}$ of Rose Bengal in $1000 \mathrm{ml}$ alcohol) to differentiate living from dead specimens (Schönfeld et al., 2012).

Samples for sedimentological analysis were cool preserved and then subjected to grain size and geochemical analysis such as total organic carbon (TOC), stable isotopes and Rock-Eval pyrolysis.

Tab. 1. Coordinates of sampling stations (GB) and physicochemical parameters of water: salinity, temperature $\left({ }^{\circ} \mathrm{C}\right), \mathrm{pH}$ and $\mathrm{O}_{2}(\mathrm{ml} / \mathrm{l})$.

\begin{tabular}{|l|c|c|c|c|c|c|}
\hline $\begin{array}{c}\text { Variables/ } \\
\text { Stations }\end{array}$ & $\begin{array}{c}\text { Latitude } \\
\mathbf{S}\end{array}$ & $\begin{array}{c}\text { Longitude } \\
\mathbf{W}\end{array}$ & Salinity & $\begin{array}{c}\text { Temperature } \\
\left(\mathbf{(}^{\circ} \mathbf{C}\right)\end{array}$ & $\mathbf{p H}$ & $\begin{array}{c}\mathbf{O}_{2} \\
(\mathbf{m g} / \mathbf{l})\end{array}$ \\
\hline GB1 & $22^{\circ} 47^{\prime} 42.33^{\prime \prime}$ & $43^{\circ} 5^{\prime} 6.29^{\prime \prime}$ & 21.8 & 30.1 & 8.4 & 6.3 \\
\hline GB2 & $22^{\circ} 46^{\prime} 16.62^{\prime \prime}$ & $43^{\circ} 4^{\prime} 32.85^{\prime \prime}$ & 21.0 & 31.8 & 8.4 & 6.3 \\
\hline GB3 & $22^{\circ} 44^{\prime} 56.03^{\prime \prime}$ & $43^{\circ} 4^{\prime} 0.82^{\prime \prime}$ & 12.5 & 32 & 8.51 & 6.1 \\
\hline GB4 & $22^{\circ} 42^{\prime} 57.70^{\prime \prime}$ & $43^{\circ} 4^{\prime} 31.16^{\prime \prime}$ & 12.1 & 32.2 & 8.22 & 6.6 \\
\hline GB5 & $22^{\circ} 43^{\prime} 7.02^{\prime \prime}$ & $43^{\circ} 6^{\prime} 6.54^{\prime \prime}$ & 35.9 & 25.0 & 7.7 & 9.7 \\
\hline GB6 & $22^{\circ} 45^{\prime} 48.52^{\prime \prime}$ & $43^{\circ} 6^{\prime} 22.53^{\prime \prime}$ & 32.7 & 31.7 & 8.34 & 7.9 \\
\hline GB7 & $22^{\circ} 48^{\prime} 48.27^{\prime \prime}$ & $43^{\circ} 5^{\prime} 38.48^{\prime \prime}$ & 33.8 & 30.9 & 8.4 & 6.4 \\
\hline GB8 & $22^{\circ} 49^{\prime} 05.2^{\prime \prime}$ & $43^{\circ} 04^{\prime} 57.5^{\prime \prime}$ & 35.7 & 29.8 & 8.27 & 5.4 \\
\hline GB9 & $22^{\circ} 48^{\prime} 33.00^{\prime \prime}$ & $43^{\circ} 4^{\prime} 27.80^{\prime \prime}$ & 31.9 & 28.6 & 8.5 & 8.6 \\
\hline
\end{tabular}




\subsection{Sedimentological analysis of surface sediment samples}

\subsubsection{Textural analyzes}

The samples for particle size analysis were dried and wet sieved through a $63 \mu \mathrm{m}$ screen. The sediment fractions $>63$ $\mu \mathrm{m}$ and $<63 \mu \mathrm{m}$ were dried and weighted.

The sediment fraction $>63 \mu \mathrm{m}$ was separated in several fractions using a battery of sieves $(125 \mu \mathrm{m}, 250 \mu \mathrm{m}, 500 \mu \mathrm{m}$, $1000 \mu \mathrm{m}$ and $2000 \mu \mathrm{m})$.

The percentage of each sediment fraction was determined. The textural classification of sediments was based on Folk and Ward (1957) using Gradistat software.

2.4.2 TOC and Rock-Eval pyrolysis of surface sediment samples

About $10 \mathrm{mg}$ of each sample were used for TOC analyses. After elimination of carbonates with $50 \%$ hydrochloric acid, the samples were analyzed in the Laboratory of Chemostratigraphy and Organic Geochemistry of Universidade do Estado do Rio de Janeiro (LGQM-UERJ), with a LECO SC-632 equipment, which directly provided the percentage of TOC.

As all the samples displayed TOC content $>1 \%$, sediments were further submitted to Rock-Eval pyrolysis analysis (Rock-Eval 6, Vinci Technologies), at the LGQMUERJ. The results of TOC content were evaluated according to Peters and Cassa (1994) (Tab. 2). Rock Eval pyrolysis is used to identify the type and maturity of organic matter and to detect petroleum potential in sediments.

According to Espitalié et al. (1977), the parameter S1 is the amount of free hydrocarbon ( $\mathrm{mg} \mathrm{HC} / \mathrm{g}$ sediment) liberated at $300^{\circ} \mathrm{C}$. The $\mathrm{S} 2$ is the amount of hydrocarbon released from cracking organic compounds (mg HC/g sediment) and heavy hydrocarbons during temperature programed pyrolysis $\left(300-600{ }^{\circ} \mathrm{C}\right)$ and is related to hydrocarbon source potential. The $\mathrm{S} 3$ represents the amount of $\mathrm{CO}_{2}$ resultant from breaking carboxyl groups and other oxygen-containing compounds, obtained at $300-390{ }^{\circ} \mathrm{C}$.

The hydrogen $[\mathrm{HI}=(\mathrm{S} 2 / \mathrm{TOC}) \mathrm{x} 100 \mathrm{in} \mathrm{mg} \mathrm{HC} / \mathrm{g}$ TOC $]$ and oxygen indices $[\mathrm{OI}=(\mathrm{S} 3 / \mathrm{TOC}) \times 100 \mathrm{in} \mathrm{mg} \mathrm{CO} / \mathrm{g}$ TOC] were calculated following the procedures of Espitalié et al. (1977). The HI is a parameter used to characterize the origin of organic matter. Marine organisms and algae are in general composed of lipid- and protein-rich organic matter, where the $\mathrm{H} / \mathrm{C}$ ratio is higher than in the carbohydrate-rich constituents of land plants. HI typically ranges from $\sim 100$ to 600 in marine geological samples.

The $\mathrm{OI}$ is a parameter that correlates with the $\mathrm{O} / \mathrm{C}$ ratio, and so it is related to the amount of oxygen in organic compounds (El Nady et al., 2015). The OI is high for polysaccharide-rich remains of land plants and inert organic material (residual organic matter) encountered in marine sediments. The $\mathrm{OI}$ values range from near 0 to $\sim 150$.

On the basis of S2, HI and Tmax values, a semiquantitative assessment of the generation potential, type and stage of thermal evolution of organic matter was performed (Espitalié et al., 1985/86).

The scales used for each case are shown in Table 2 (Espitalié et al., 1977; 1985/86). The production index (PI) values also were determined using the formula: $\mathrm{S} 1 / \mathrm{S} 1+\mathrm{S} 2$. PI is used to characterize the evolution level of the organic matter.

\subsubsection{Carbon stable isotopes $\left(\delta^{13} \mathrm{C}\right)$ in sedimentary organic} matter

The carbon stable isotopes of organic matter were analyzed at the LGQM-UERJ. After the removal of carbonates with $\mathrm{HCl} 1 \mathrm{M}$ hydrochloric acid, the samples were washed with Milli-Q water to removal the acid and dried in an oven and desegregated with an agate mortar. After these procedures, $\delta^{13} \mathrm{C}$ values were determined using Elemental analyzer coupled to Delta V Mass Spectrometer. The standard deviation of the analysis is $0.15 \%$.

\subsection{Living foraminifera analysis in surface sediment}

Living benthic foraminifera analyses were performed in Laboratory of Micropaleontology of Universidade do Estado do Rio de Janeiro (LMP-UERJ). The rose Bengal treated samples collected in triplicates (about $50 \mathrm{ml}$ ) at each site were combined analyzed. The sediment fraction $>63 \mu \mathrm{m}$ was wet sieved through a $63 \mu \mathrm{m}$ mesh screen. After washing, the samples were dried in an oven at $\approx 50^{\circ} \mathrm{C}$. The sediments fractions $<63 \mu \mathrm{m}$ were discarded. The sediment fraction $>63$ $\mu \mathrm{m}$ was dry sieved through a $500 \mu \mathrm{m}$ screen. Both dry sediment fractions, $63-500 \mu \mathrm{m}$ and $>500 \mu \mathrm{m}$, were analyzed. However, no foraminifera were found in the $>500 \mu \mathrm{m}$ fraction. Thus foraminiferal assemblages dimension, structure and composition were evaluated in the sediment fraction $63-500 \mu \mathrm{m}$. 
Tab. 2. Semi-quantitative scales assessment of TOC content according to Peters and Cassa (1994), potential generator of organic matter $\left(\mathrm{S}_{2}\right)$, hydrogen index $(\mathrm{IH})$ and organic matter maturation - Tmax $\left({ }^{\circ} \mathrm{C}\right)$, based on Espitalié et al. $(1977 ; 1985 / 86)$.

\begin{tabular}{|l|l|}
\hline \multicolumn{2}{|c|}{ Total Organic Carbon TOC $(\%$; Peters and Cassa, 1994) } \\
\hline$<0.5$ & Poor \\
\hline $0.5-1.0$ & Moderate \\
\hline $1.0-2.0$ & Good \\
\hline $2.0-4.0$ & Very Good \\
\hline$>4.0$ & Excellent \\
\hline \multicolumn{2}{|c|}{ Potential generator of organic matter $\mathrm{S}_{2}(\mathrm{mg} \mathrm{HC} / \mathrm{g}$ sediment $)$} \\
\hline$<2.0$ & Low potential generator \\
\hline $2.0-5.0$ & Moderate source potential \\
\hline $5.0-10$ & Good source potential \\
\hline$>10$ & Excellent source potential \\
\hline \multicolumn{2}{|c|}{ Hydrogen Index $-\mathrm{HI}[($ mg HC/g TOC) $\mathrm{x} 100]$} \\
\hline IH $<200$ & Gas Potential \\
\hline $200<$ IH $<300$ & Gas and Condensate Potential \\
\hline IH $>300$ & Oil Potential \\
\hline \multicolumn{2}{|c|}{ Maturation - Tmax $\left({ }^{\circ} \mathrm{C}\right)$} \\
\hline$<440$ & Immature \\
\hline $440-470$ & Mature \\
\hline$>470$ & Senile \\
\hline
\end{tabular}

Foraminiferal density (FD) as the number of living specimens (stained) per gram of sediment was calculated. The assemblages of living foraminifera were characterized by counting at least 300 specimens of rose Bengal stained foraminifera per sample.

The generic taxonomical classification of Loeblich and Tappan (1987), and specific concepts of Cushman and Brönniman (1948 a, b), Boltovskoy et al. (1980), Debenay et al. (1998; 2001), Martins and Gomes (2004) and Laut et al. (2012a) were followed. After identification, the species names were checked in World Register of Marine Species (WoRMS: http://www.marinespecies.org/index.php; accessed on 01.09.2016). The specimens were stored in micropaleontological slides (as suggested by Schönfeld et al., 2012).

The percentage of each species per sample was determined. Several assemblages' parameters were also calculated. The number of species found in each sample, named richness of species (S) was determined. The Shannon index $\left(\mathrm{H}^{\prime}\right)$ was used as measure of diversity: $\mathrm{H}^{\prime}=\Sigma$ pi Ln pi, where pi represents the portion of $i$ - species in the sample and $\mathrm{Ln}$ is the natural (base e) logarithm. Equitability or evenness (J') was obtained through $\mathrm{J}^{\prime}=\mathrm{H}^{\prime} / \mathrm{Ln}(\mathrm{S})$, where $\mathrm{S}$ is the richness of species, $H^{\prime}$ is the Shannon diversity index and Ln the natural (base e) logarithm. These biotic parameters were determined with the software Primer 6.

\subsection{Statistical Analysis}

As a very limited number of living specimens was found at station GB8, this sample was not considered in statistical analysis. The most frequent foraminiferal species (with a relative abundance $\geq 3 \%$ in at least one site) were further used in the statistical analysis. Before the statistical analysis the biotic and abiotic data were logarithmically transformed $\log (\mathrm{X}+1)$. Principal components analysis was carried out in 
Statistica 12.0. Maps were performed with Arc Gis 9.2® using coordinates according to WGS84 (UTM zone $23 \mathrm{~S}$ ) datum.

\section{Results}

\subsection{Acoustic signatures and core sediment properties}

The analysis of seismic profiles revealed a large area, of about $50 \%$ of the total analyzed area, affecting signal penetration due to gas charged sediments. Following the classifications of Taylor (1992) and Baltzer et al. (2005), it was possible to identify acoustic signatures of black shadow and acoustic blanket. Features related to percolation of gas as intra sedimentary plumes, turbidity pinnacle, and structures related to seepages to the water column, as acoustic plumes and pockmarks were also identified.

The black shadow (BS) is a very dark signal commonly with sharp lateral limits and multiple distinct reflections to the end of the profile (Fig. 2). It differs from the acoustic blanket because it is not possible to detect the signal penetration into the substrate, all the signal energy appears to be reflected by the surface sediments (Baltzer et al., 2005). When the acoustic blanket (AB-I) is a few centimeters deep and up to $1.3 \mathrm{~m}$ below the bottom surface it generates diffuse and more attenuated sequences of surface multiple due to less reflected energy than the black shadow. When the acoustic blanket (AB-II) is lying at depths between $1.3 \mathrm{~m}$ and $9 \mathrm{~m}$ below the bottom surface there is no seismic signal below its occurrence (Fig. 2). Turbidity pinnacles and intrasedimentary plumes appear as gas percolation seepages into the sediment originated from the acoustic blanket - II (Fig. 2).

Turbidity pinnacles develop towards the surface and range between 1 and $2 \mathrm{~m}$ in height, while the intrasedimentary plumes can reach up to $7.5 \mathrm{~m}$ toward the surface. Acoustic plumes appear in several dimensions. The largest one is $3 \mathrm{~m}$ in height and $12 \mathrm{~m}$ width located in deeper water near Paquetá Island. The smallest one, with $0.5 \mathrm{~m}$ height and $2.5 \mathrm{~m}$ width, is located in shallower areas.

The cores (with 150-240 cm in length) are composed by muddy sediments, passing from fluid mud at the top to compacted mud in the base. Bioturbation structures and many bioclasts were observed along the cores. Cores are composed by the following sediment fractions: silt (83-93\%), very fine sand $(0.1-17.2 \%)$ and clay $(3-12.6 \%)$ (Fig. 3). Regarding $\mathrm{OM}$ and carbonate contents, the percentages range from $11-22 \%$ and from $3.8-11.6 \%$, respectively (Fig. $3)$. The OM percentage gradually decreases with increasing depth, while the carbonate content is variable along the cores. The geotechnical properties of shear strength (SS) and cohesive force (CF) is lower at the top, where the water mass is 3.85 times greater than the dry solid mass. From $100 \mathrm{~cm}$ deep to the base, the values of SS $\left(0.26-0.72 \mathrm{~kg} . \mathrm{cm}^{-2}\right)$ and CF $\left(0.04-0.11 \mathrm{~kg} . \mathrm{cm}^{-2}\right)$ increase and water mass content decrease (1.27-2.26). The range of P-wave velocity (Vp), Gamma density, magnetic susceptibility and electrical resistivity measured along the cores T1-T4 are shown in Table 3.

The depth plots of these variables along the cores T1 and T2 are presented in Figure 3. In gas free sediments, the density values ranging from 1.08 to $1.48 \mathrm{~g}^{\cdot} \mathrm{cm}^{-3}$ and the $\mathrm{Vp}$

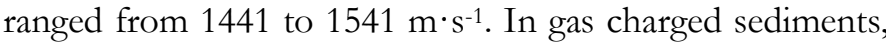
density varied between 1.10 and $1.46 \mathrm{~g}^{\circ} \mathrm{cm}^{-3}$ and $V p$ between 1372 and $1505 \mathrm{~m} \cdot \mathrm{s}^{-1}$. All cores show a general trend of increasing in density values from the top to the base. However, punctual decreases of these values were observed along the cores (Fig. 3).

The radiocarbon dating showed that sediment accumulation rates are smaller in core T1 and higher in cores $\mathrm{T} 2$ and $\mathrm{T} 4$. Core $\mathrm{T} 1 \mathrm{~h}$ as small accumulation increments from 0.03 to $0.09 \mathrm{~cm}_{\text {.year }}{ }^{-1}$ in the last $4,000 \mathrm{BP}$, while cores T2 and $\mathrm{T} 4$ showed a significant increase in accumulation rates from 0.16 to $0.90 \mathrm{~cm}_{\text {.year }}{ }^{-1}$ in the last 200 years.

\subsection{Abiotic variables related to the event for sampling surface sediment}

During surface sedimentsampling, the water temperature varied between $25^{\circ} \mathrm{C}$ and $32.2^{\circ} \mathrm{C}$ (mean $30.2^{\circ} \mathrm{C}$ ), salinity from 12.1 to 35.9 (mean 24.4; Fig. 4A) and $\mathrm{pH}$ from 7.7 to 8.5 (mean 8.3) (Tab. 1). The DO in the water column ranged from $5.4-9.7 \mathrm{mg} / 1$ (mean $7.0 \mathrm{mg} / \mathrm{l}$ ). Temperatures were relatively elevated agreeing with the summer season. The lowest values of salinity were recorded near the rivers out flow of the NE region of Guanabara Bay (GB) and of $\mathrm{pH}$ in station GB5, located near the Surui River mouth.

The estimated sediment mean grain size varied between 17-124 $\mu \mathrm{m}$ (mean $41.9 \mu \mathrm{m}$ ) with fine fraction ranging from $27 \%$ to $94.6 \%$ (mean $72.9 \%$; Fig. 4B; Tab. 4). In most of the analyzed sites mud and sandy mud compose the substrate.

In the studied surface sediment samples the following (Tab. 4) variations were observed: TOC between 1.5-5.8\% (mean $3.7 \%$; Fig. $4 \mathrm{C}$ ); $\delta^{13} \mathrm{C}$ between $-21.6 \%$ to $-24.6 \%$ (mean -23.1\% ; Fig. 4D), S1 between 0.5-1.8 mg HC/g (1.0 mean mg HC/g; Fig. 5A); S2 between 2.7-10.5 mg HC/g (mean $6.2 \mathrm{mg} \mathrm{HC} / \mathrm{g}$; Fig. 5B) and; $\mathrm{S} 3$ between $2.2-7.6 \mathrm{mg}$ $\mathrm{CO}_{2} / \mathrm{g}$ (mean $5.5 \mathrm{mg} \mathrm{CO} / \mathrm{g}$; Fig. 5C). 


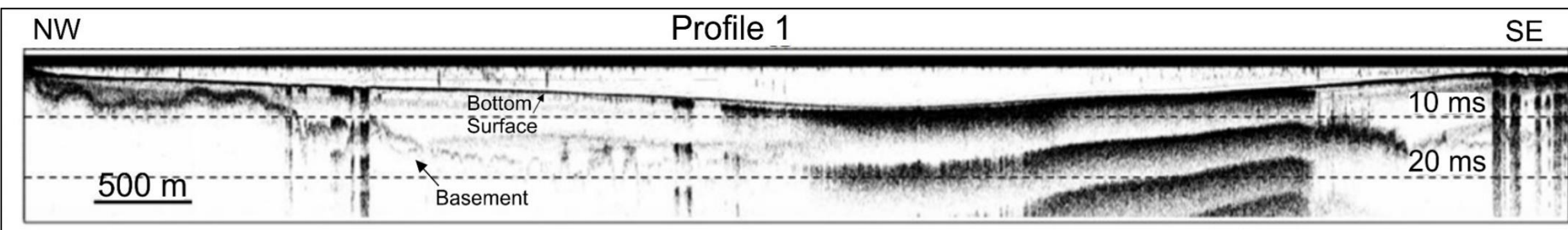

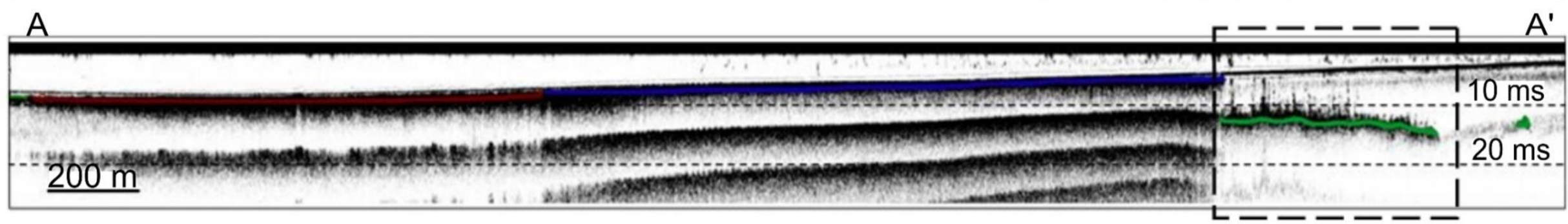
A. Blancket - I

B. Shadow

A. Blancket - II
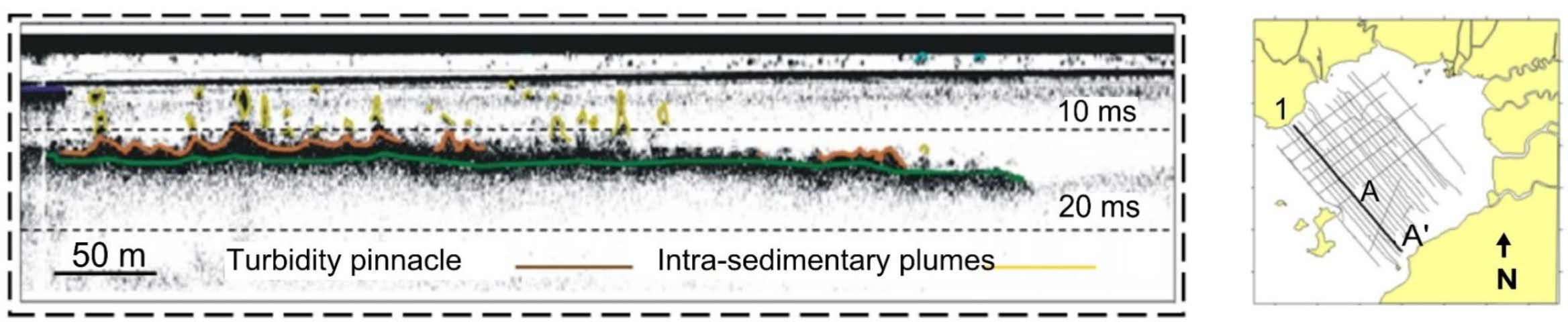

Fig. 2. Profile 1 displaying the identified acoustic signatures. 


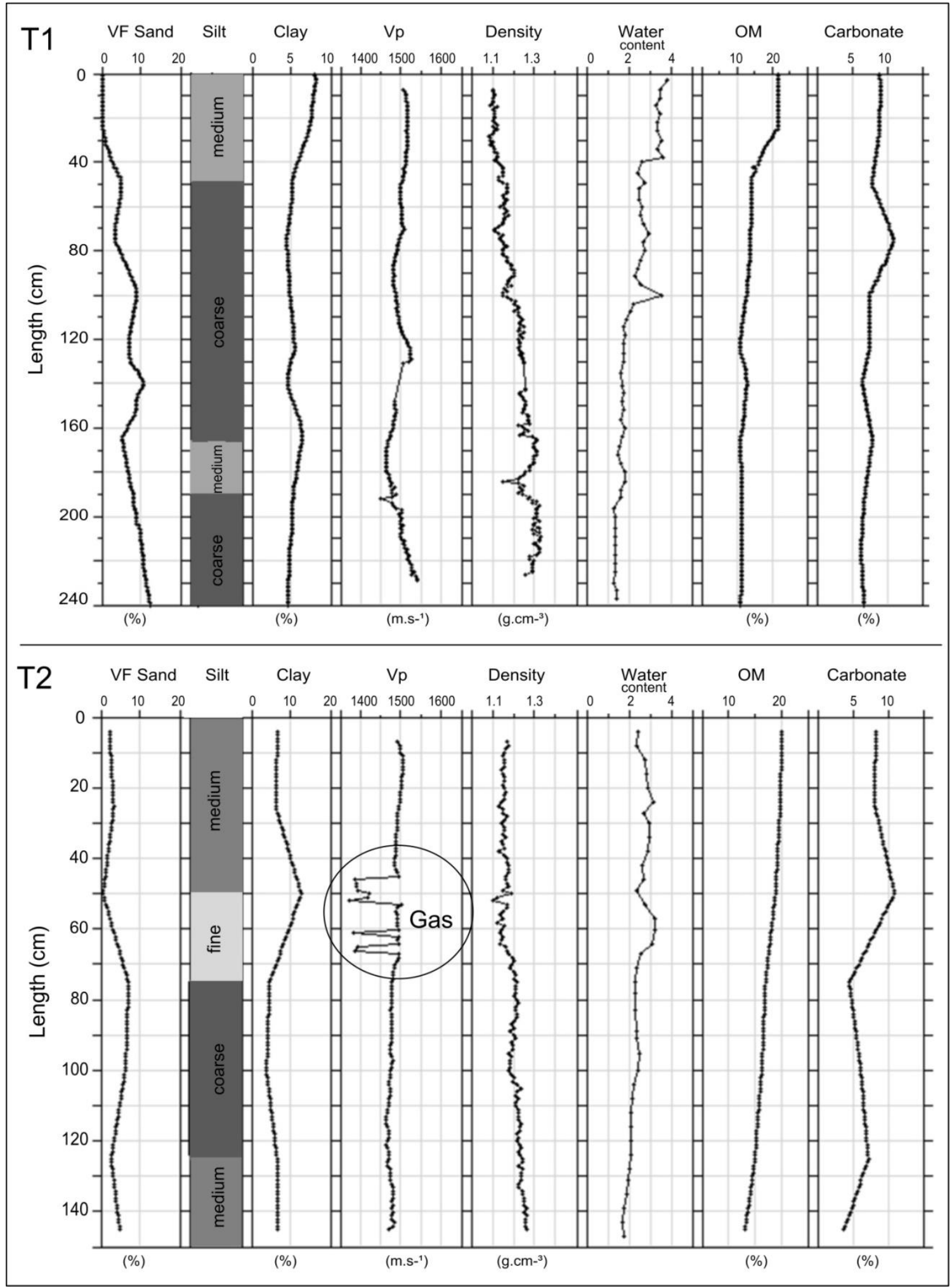

Fig. 3. Depth plots of grain size, $\mathrm{P}$-wave velocity $(\mathrm{Vp})$, density, water content, organic matter $(\mathrm{OM})$ and carbonate parameters in the cores T1 (gas free sediments) and T2 (gas charged sediments). 
Tab. 3. Range of P-wave velocity (Vp), Gamma density, electrical resistivity (ER) and magnetic susceptibility (MS) at cores T1-T4.

\begin{tabular}{|c|c|c|c|c|c|c|c|c|c|c|}
\hline Core & Sediment & $\begin{array}{l}\text { Length } \\
\text { (cm) }\end{array}$ & \multicolumn{2}{|c|}{$\begin{array}{c}\mathrm{Vp} \\
\left(\mathrm{m} \cdot \mathrm{s}^{-1}\right)\end{array}$} & \multicolumn{2}{|c|}{$\begin{array}{l}\text { Density } \\
\left(\text { g.cm }{ }^{-3}\right)\end{array}$} & \multicolumn{2}{|c|}{$\begin{array}{c}\text { ER } \\
(\Omega . m)\end{array}$} & \multicolumn{2}{|c|}{$\begin{array}{c}\text { MS } \\
\left(\times 10^{-5} \mathrm{SI}\right)\end{array}$} \\
\hline T1 & \multirow{2}{*}{ free gas } & 240 & 1450 & 1541 & 1.08 & 1.33 & 0.54 & 1.98 & -3.6 & 5.0 \\
\hline T3 & & 180 & 1441 & 1487 & 1.24 & 1.48 & 0.71 & 1.37 & 0 & 7.2 \\
\hline $\mathrm{T} 2$ & charged gas & 150 & 1372 & 1505 & 1.10 & 1.26 & 0.51 & 0.87 & -0.19 & 6.4 \\
\hline
\end{tabular}
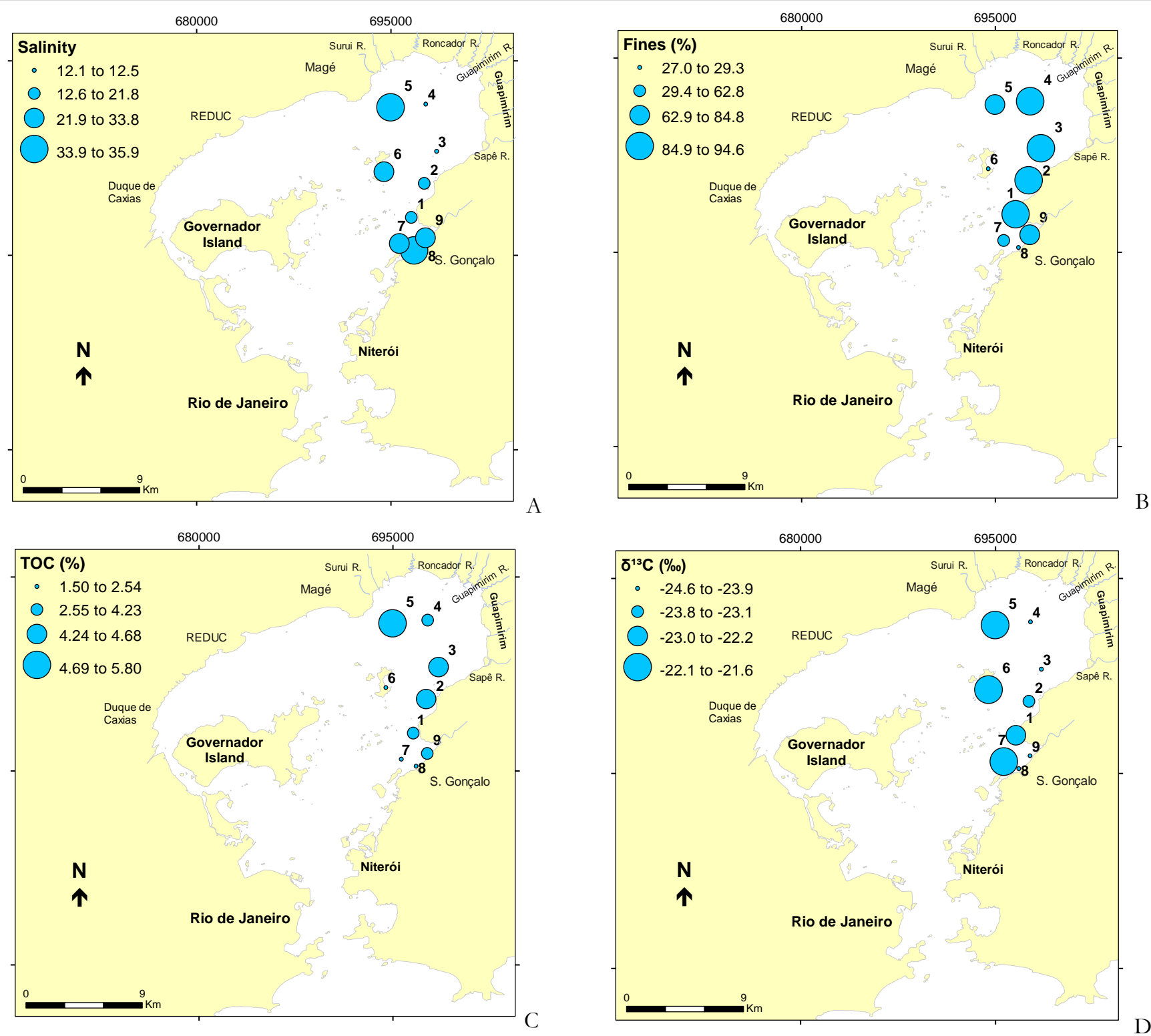

Fig. 4. Maps of distribution: A. Salinity; B. Fine fraction (Fines; \%); C. TOC (\%); and D. $\delta^{13} \mathrm{C}(\%)$. 

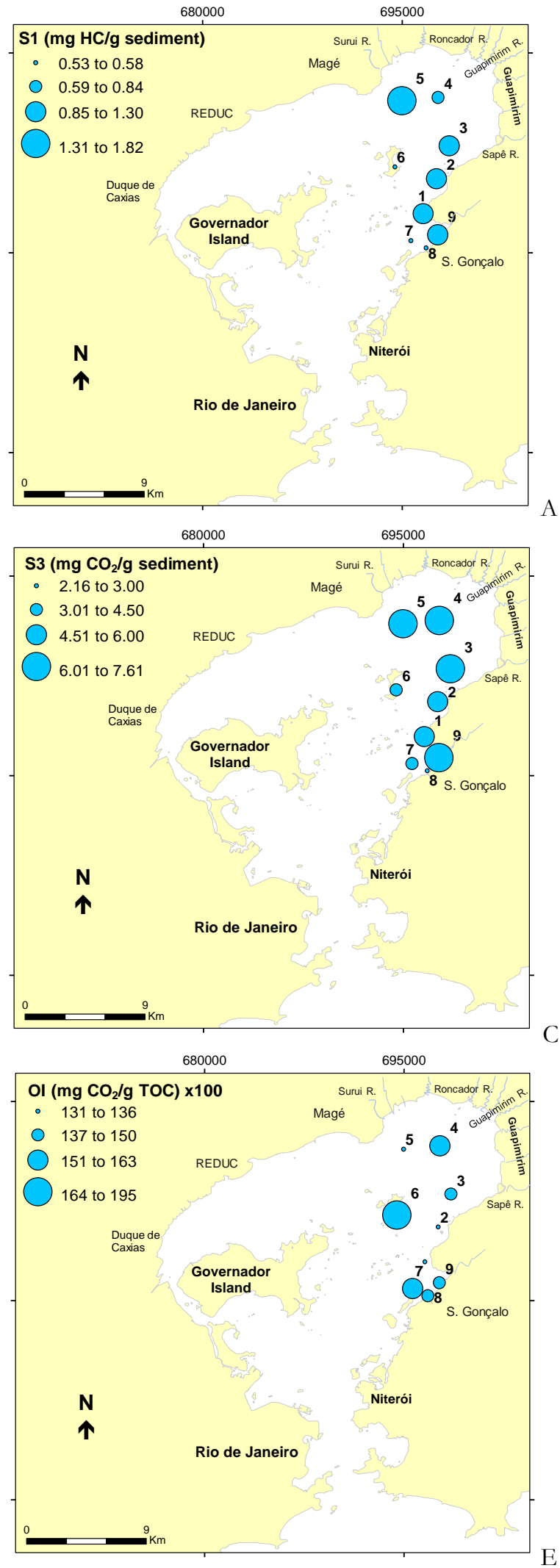
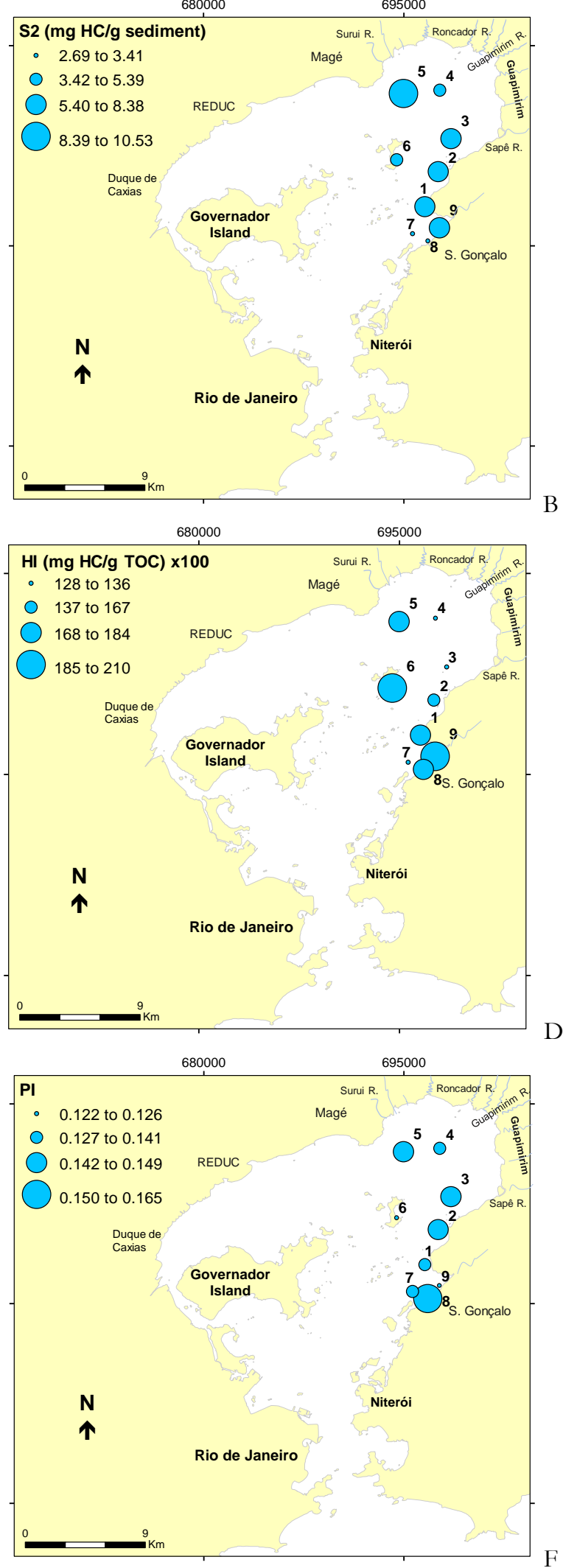
Fig. 5. Maps of distribution of Rock-Eval pyrolysis parameters, namely: A.S1 (mg HC/g sediment);B. S2 (mg HC/g sediment);C. S3 mg $\mathrm{CO}_{2} / \mathrm{g}$ sediment; D. Hydrogen Index [HI; (mg HC/g TOC) x100]; E. Oxygen Index [OI;(mg CO $2 / g$ TOC) x100] and;F. Production Index (PI).

The hydrogen index (HI) ranged from 127.7 to $210.1 \mathrm{mg}$ $\mathrm{HC} / \mathrm{g}$ TOC (mean $168.7 \mathrm{mg} \mathrm{HC} / \mathrm{g}$ TOC; Fig. 5D) and oxygen index (OI) from $131.2 \mathrm{mg} \mathrm{CO} / \mathrm{g}$ TOC to $195.5 \mathrm{mg}$ $\mathrm{CO}_{2} / \mathrm{g}$ TOC (mean $150.4 \mathrm{mg} \mathrm{CO} / \mathrm{g}$ TOC; Fig. 5E). The Tmax values are $<440{ }^{\circ} \mathrm{C}$. The production index (PI) values (S1/S1+S2) oscillated between 0.12-0.16 (Fig. 5F). The most positive $\delta^{13} \mathrm{C}$ values were recorded in the stations located nearer the Guanabara Bay connection with the ocean as well as $\mathrm{HI}$ index values.

\subsection{Living benthic foraminifera in surface sediment}

Data of foraminifera are presented in Appendix 1. Living FD is $<3487$ ind/g of bulk sediment (Fig. 6A), $\mathrm{H}^{\prime}$ is $<1.74$ (Fig. 6B) and J' is $<0.57$. These values are indicative of low abundance, diversity and equitability of living foraminifera assemblages in the studied stations. In these stations, 44 species of living foraminifera were identified. The most abundant species by decreasing order are: Ammonia tepida (48-95\%), Cribroelphidium excavatum (0.3-32\%\%), Ammotium

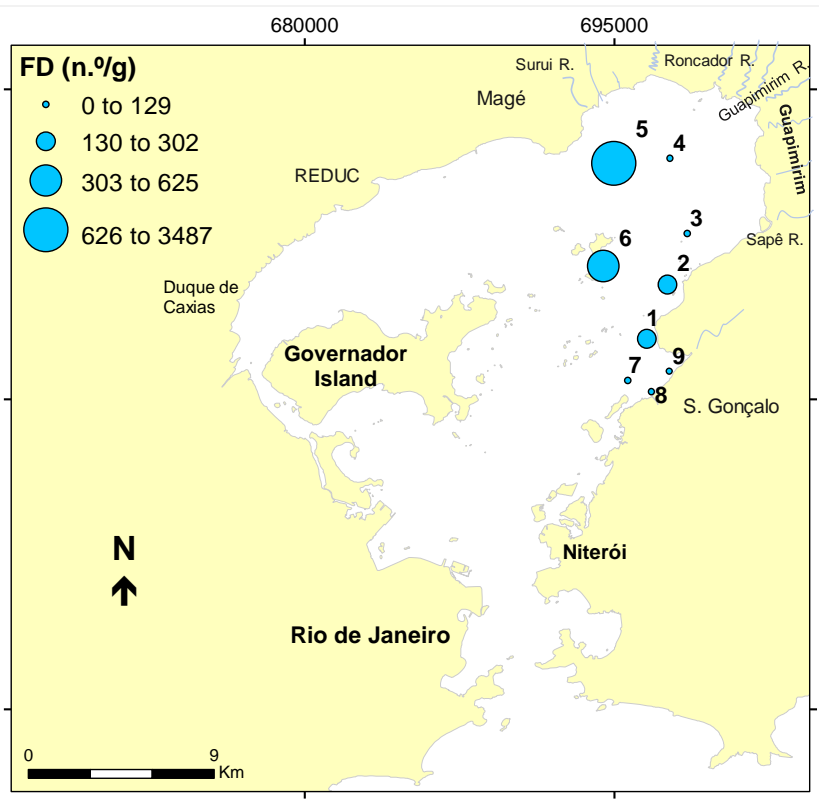

A salsum $(<15 \%)$, Bolivina striatula $(<12 \%)$, Gavelinopsis praegeri $(<9 \%)$, Buliminella elegantissima $(<8 \%)$, Discorbis parkeri $(<7$ $\%)$, Reophax nana (<6\%), Elphidium gerthi $(<5 \%)$, Bolivina compacta $(<3 \%)$ and Rosalina floridana $(<3 \%)$.

\subsection{Principal Components Analysis (PCA)}

Factor 1 and Factor 2 of the PCA presented in Figure 7 explain together most part of data variability $(63 \%$, contributing with $43 \%$ and $20 \%$, respectively). The PCA separated four groups of variables.

Group 1 is composed by B. striatula, G. praegeri, D. parkeri, E. gerthi, B. compacta and R. floridana, H', J' and S. These species are more common in the outer sector of the study area. The variables of Group 1 are negatively related to the Group II, which includes TOC, S1, S2, S3 and fine fraction. Group 3 contains A. tepida, B. elegantissima, PI and FD and is in opposition to Group 4 that is composed by $C$. excavatum and $A$. salsum.

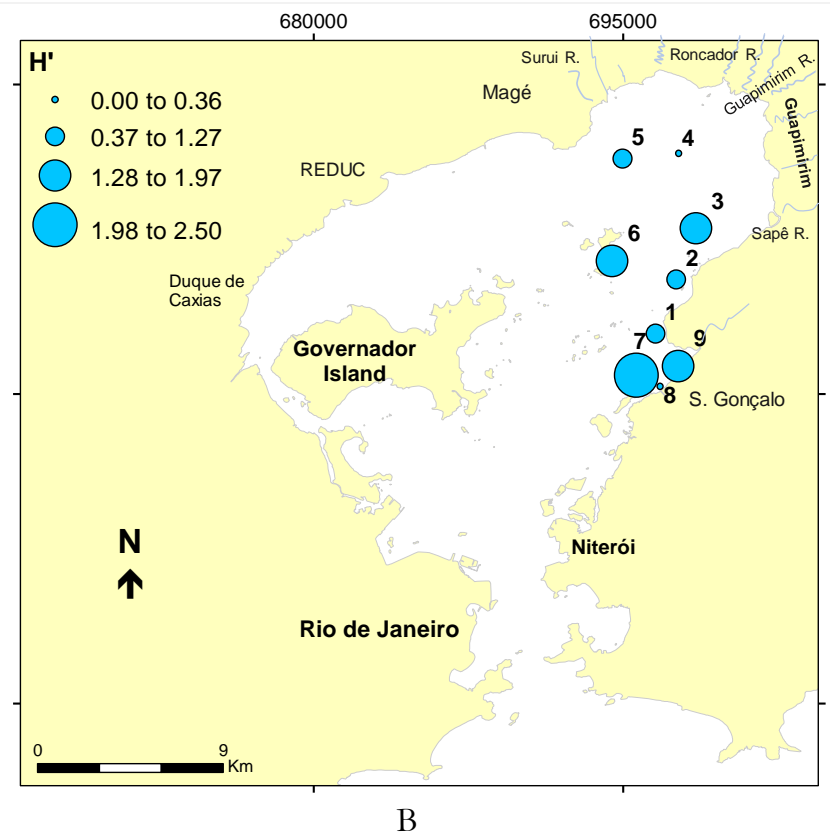

Fig. 6. Maps of distribution of: A) foraminiferal density (FD; n. ${ }^{\circ}$ g) and; B) Shannon Index (H'). 


\section{Discussion}

\subsection{Surface sediments}

The grain size of surface samples indicates that in most part of the studied sites the bottom currents are weak and favorable to the deposition of fine grained sediments enriched in organic matter (mean TOC values 3.7\%) on the bottom of the Guanabara Bay. This is also supported by the significant positive correlations between TOC and sedimentary fine fraction. These results of surface sediments well agree with data obtained from sediment cores presented in this work and also that performed by Figueiredo Jr. et al. (2014).

In costal environments, carbon origins consist of complex mixtures from autochthonous and allochthonous sources. The isotopic composition of organic matter $\left(\delta^{13} \mathrm{C}\right.$ and $\delta^{15} \mathrm{~N}$ ) obtained by Carreira et al. (2002) in surface sediments (vertical cores collected at eight locations) allowed to verify that in the Guanabara Bay, a mixture of marine, land and estuarine sources of organic matter is present. The $\delta^{13} \mathrm{C}$ values of organic matter produced from atmospheric $\mathrm{CO}_{2}$ by C3 terrestrial plants range from $-23 \%$ to $-34 \%$, while C4 plants have $\delta^{13} \mathrm{C}$ values between $-9 \%$ and $-17 \%$ (Schubert and Calvert, 2001).

Marine organic matter has $\delta^{13} \mathrm{C}$ values ranging between $20 \%$ and $-22 \%$ (Meyers, 1994). The $\delta^{13} \mathrm{C}$ values found in the studied samples (ranging from $-21.60 \%$ to $-24.56 \%$; mean $-23.1 \pm 1.5 \%$ ) can suggest that the NE part of Guanabara Bay receives predominately organic matter from higher plants.

Carreira et al. (2002) reported an increase of inputs of terrestrial organic matter in recent years in the bay. They also verified that although high respiration rates occurring in the water column, rapid sedimentation rates therein result in the transfer of a significant proportion of carbon to the anoxic sediments. In the stations where surface samples were collected sediments displayed dark gray to black color that might suggest reducing conditions just some millimeters below the water-sediment interface.

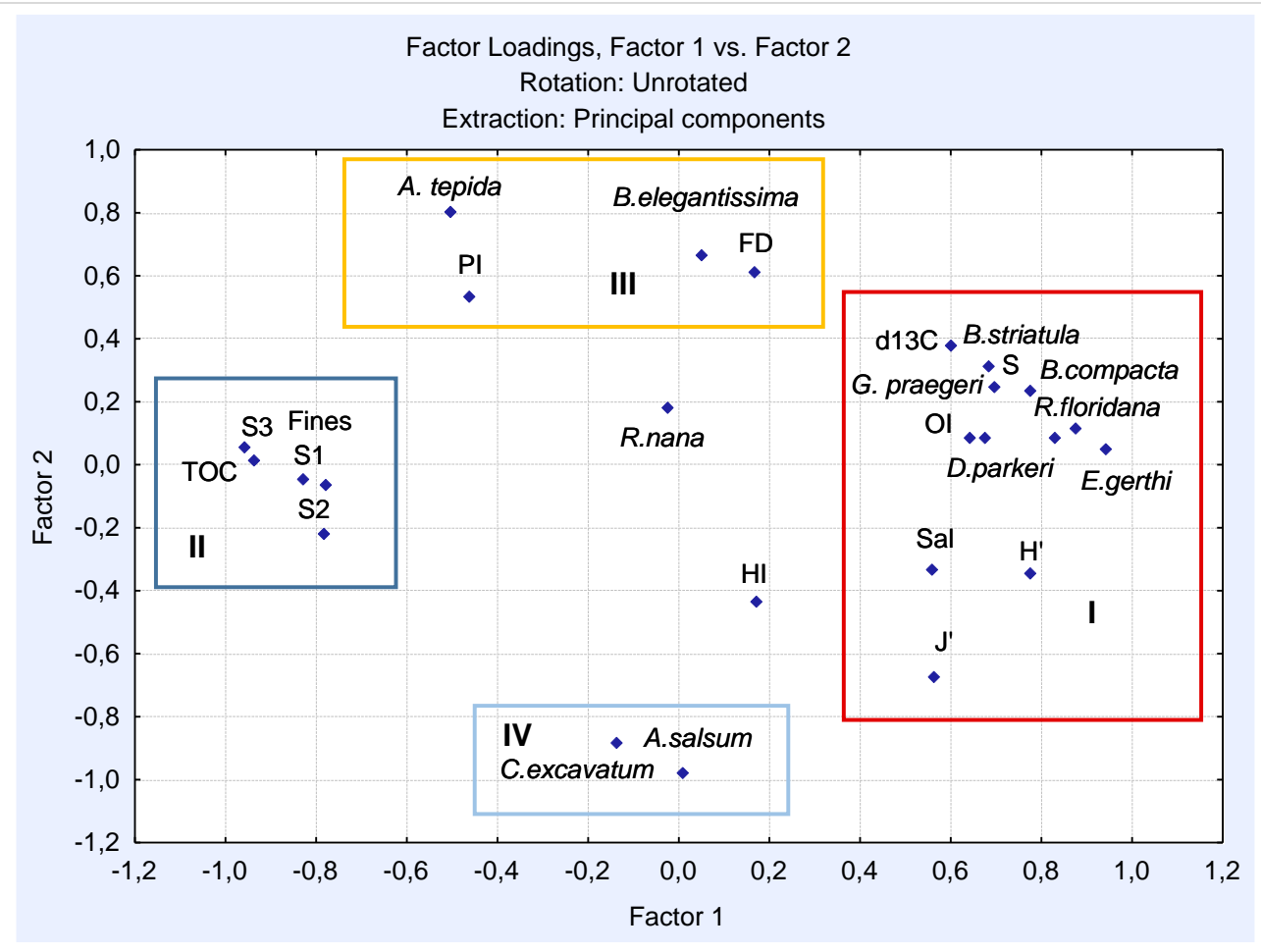

Fig. 7. Results of PCA for the first two components, based on the percentage of the main species of benthic foraminifera, foraminiferal density (FD; $\mathrm{n}^{\circ} / \mathrm{g}$ ), specific richness (S), Shannon index (H') and equitability (J'). Some abiotic variables also were used: salinity (sal); sedimentary fine fraction content (Fines; \%);total organic carbon (TOC; \%); $\delta^{13} \mathrm{C}(\mathrm{d} 13 \mathrm{C} ; \%$ ) and Rock-Eval pyrolysis parameters, namely $\mathrm{S} 1$ (mg HC/g sediment),S2 (mg HC/g sediment),S3(mg CO $2 / g$ sediment), hydrogen index [HI; (mg HC/g TOC) x100]; oxygen index [OI; (mg CO $2 / g$ TOC) x100] and production index (PI). 
The values of TOC, fine fraction, S1, S2 and S3 present a similar pattern of distribution as indicated by the results of PCA (Fig. 7). Accordingly, the highest TOC content results in a higher source generation potential (indicated by S2 values) and free hydrocarbon content (indicated by S1), and can give place to a higher production of $\mathrm{CO}_{2}$ (indicated by S3 values) from organic matter degradation. Peters (1986) and Espitalié et al. (1970, 1980, 1985/86) reported that oil generation from source rocks began at Tmax $=435-465^{\circ} \mathrm{C}$, and production index "PI" between 0.2 and 0.4 . The organic matters are in an immature stage when "Tmax" has a value $<435^{\circ} \mathrm{C}$, and "PI" $<0.1$ and the gas generation from source rocks began at "Tmax" $470{ }^{\circ} \mathrm{C}$, and production index "PI" $>0.4$. Thus, the $\mathrm{Tmax}$ values $\left(<440{ }^{\circ} \mathrm{C}\right)$ in the studied samples suggest that the organic matter in surface sediments are thermally immature, which is in agreement with the geological context. Being the organic matter immature, it can be expected that the PI was $<0.10$ (Espitalie et al., 1985/86). However, the estimated PI values are $>0.10$, suggesting that the samples are contaminated by oil released probably by boats and by the activities of the oil refineries such as the REDUC, Duque de Caxias. Moreover, as the organic matter is terminally immature, the TOC content and the S2 (related to the source potential) and HI values can be considered originals, signifying a presence of good to excellent amount of organic matter associated with moderate to good source potential for gas production. Plotting the analyzed samples on a diagram of Van Krevelen type (van Krevelen, 1950; Fig. 8), the predominance of organic matter content of Type III can be observed. This kind of organic matter, when subjected to anaerobic bacterial degradation or to high temperatures, can give place to gas production.

\subsection{Distribution of gas and core sediment properties}

Geophysical results presented in this work evidences that gas charged sediments are distributed from the Paquetá Island until the innermost area of the Guanabara Bay, and mainly towards the São Gonçalo margin (Fig. 9). The distribution of gas acoustic signatures when correlated with bathymetry, it is associated with higher topographic gradient area $(\mathrm{E} / \mathrm{NE})$. This margin receives the influence of most significant drainage from the basin of the Guanabara Bay (Figueiredo Jr. et al., 2014). The bottom sediments at the gas occurrence area are classified as coarse silt to very coarse silt and in this zone the organic matter content can reach 10$20 \%$ (Galvão, 2014). Black shadow occurs in 59.3\% and acoustic blanket occurs in $40.7 \%$ of the total gas charged sediments. The shallow gas vertical distribution ranges from surface sediments to $9 \mathrm{~m}$ below the interface water-sediment.
The spatial distribution of the different types of gas signatures depends to some extent on the overlying lithology, but can be also associated with the amount of gas trapped in sediment. Thus a high concentration of gas might favor its release (Missiaen et al., 2002). Garcia-Gil et al. (2002) showed that presence of gas in sediments is closely linked to Holocene mud because its ability in trapping underlying gas reservoir. Such connection can also be true for the gas charged sediments in the studied bay because deposition of muddy fluvial and marine Holocene sediments over Pleistocene sediments according to the evolution of the bay (Amador, 1980 a-b; Galvão, 2014). The origin of gas in Guanabara Bay is biogenic, since the geology of the area does not suggest possible thermogenic sources. Therefore, gas generation is a result of the high sediment accumulation rate, from 0.03 to $0.90 \mathrm{~cm} \cdot \mathrm{yr}^{-1}$, and intense input of organic matter in the area.

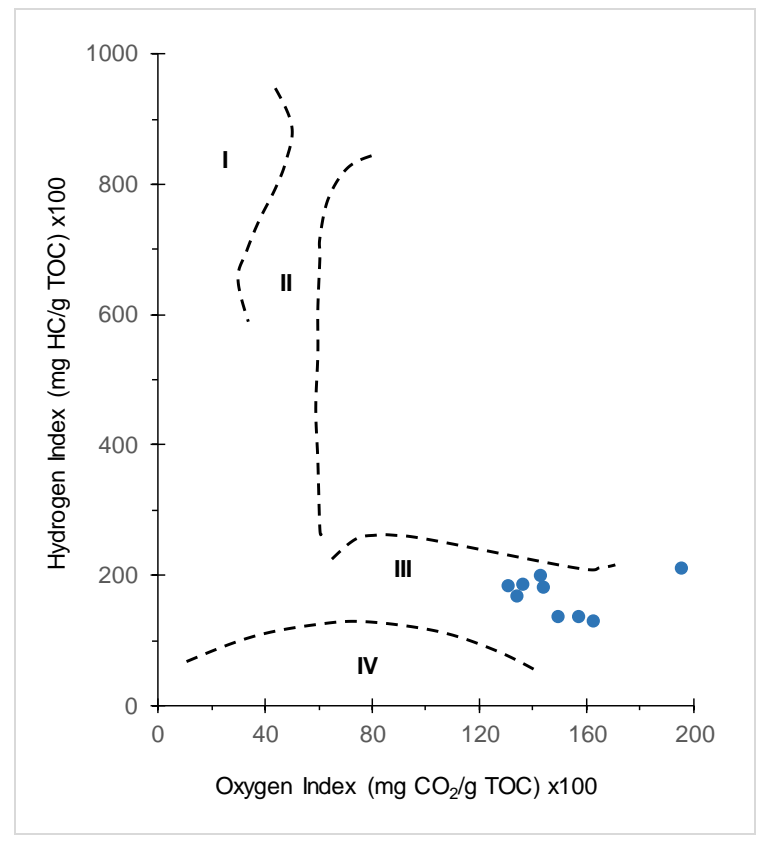

Fig. 8. Diagram of Van Krevelen type (van Krevelen, 1950).

The black shadow (BS) is associated with the recent generation of gas in the surface sediments and is typically related to the input of organic matter (Baltzer et al., 2005). Furthermore, in this study the BS signatures are related to both the migration from the lower layers and the recent generation in near-surface sediments (Figs. 9 and 10) as the area presents favorable conditions for gas production, as indicated by geochemical data. The density decrease along the cores agrees with the reduction in $\mathrm{Vp}$. According to Ayres Neto (1998), the geological factors that control the Vp 
in marine sediments are porosity, density and confinement pressure and, in general, there is a trend of increase in $\mathrm{Vp}$, with decreased porosity and an increase in density. Decreases in $\mathrm{Vp}$ and density in gas free sediments are linked with the reduction of fine sand percentage and increase in the percentage of clay, water content and carbonate shells (Fig. 3). On the other hand, in gas charged sediments, besides the already mentioned factors, the reduction in density values are mainly associated with the presence of the gas and the large percentage of OM (13\% to $20 \%)$.

Core T2, for example, shows that the intervals with lower Vp velocities, $1372-1400 \mathrm{~m} \cdot \mathrm{s}^{-1}$, recorded at $45 \mathrm{~cm}$ to $70 \mathrm{~cm}$ (Fig. 3), are associated with a layer of dark mud, where circular structures caused possibly by bubbles marks were observed in the sediment. The existence of trapped gas bubbles in sediment layers produced by biochemical degradation of organic matter, scatter and attenuate sound (Hamilton, 1972) since volumes of $0.1 \%$ can affect the geoacoustic behavior of sediment (Ayres Neto, 1998). All cores showed very low magnetic susceptibility (maximum $7.98 \times 10^{-5} \mathrm{SI}$; minimum $-3.6 \times 10^{-5} \mathrm{SI}$ ). This can be attributed to significant concentrations of organic matter and biogenic materials and sometimes to presence of diamagnetic minerals, which weaken the magnetic field (Ellwood et al., 2006).

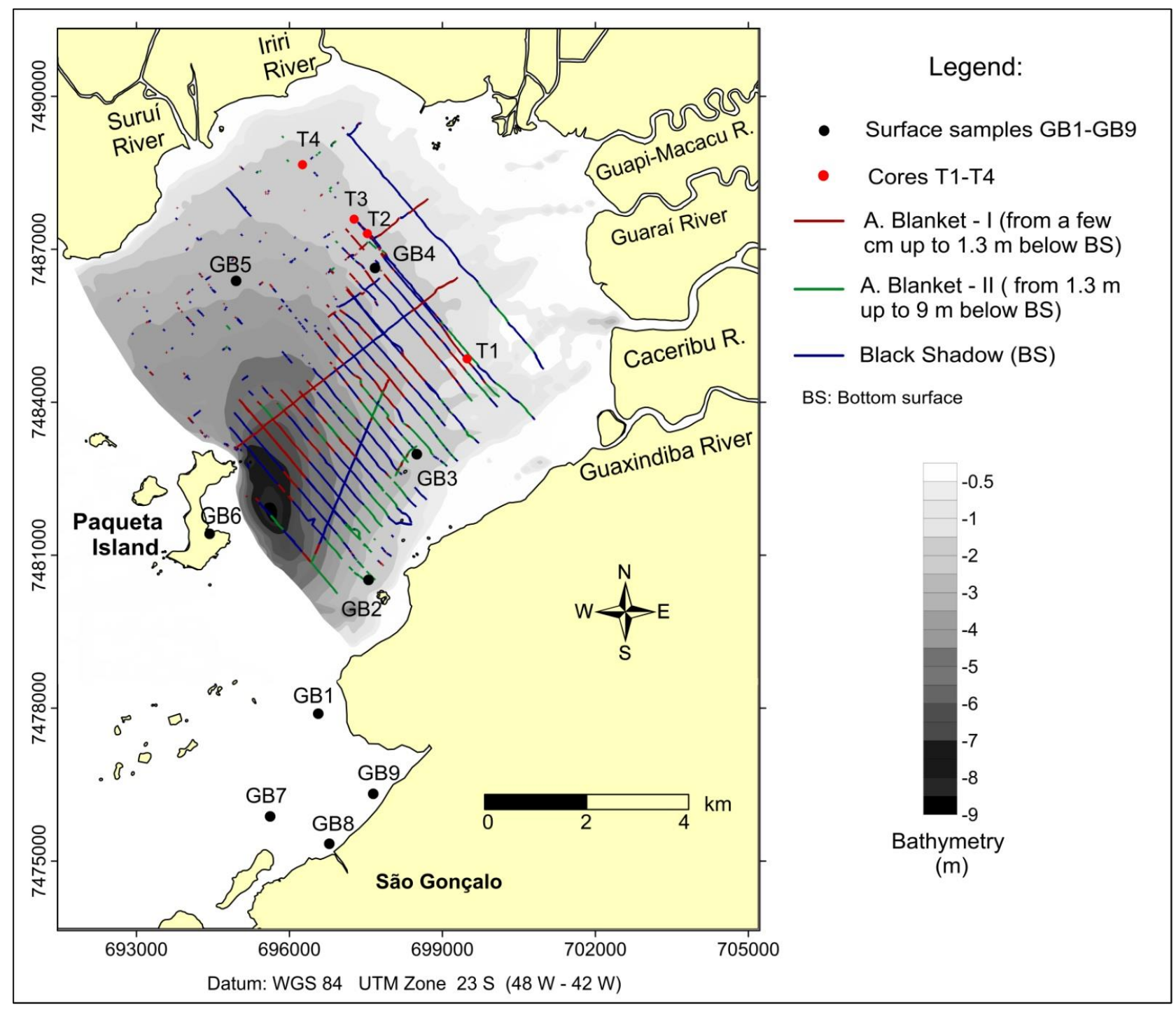

Fig. 9. Gas acoustic signature distribution in Guanabara Bay superimposed on bathymetric contours. 


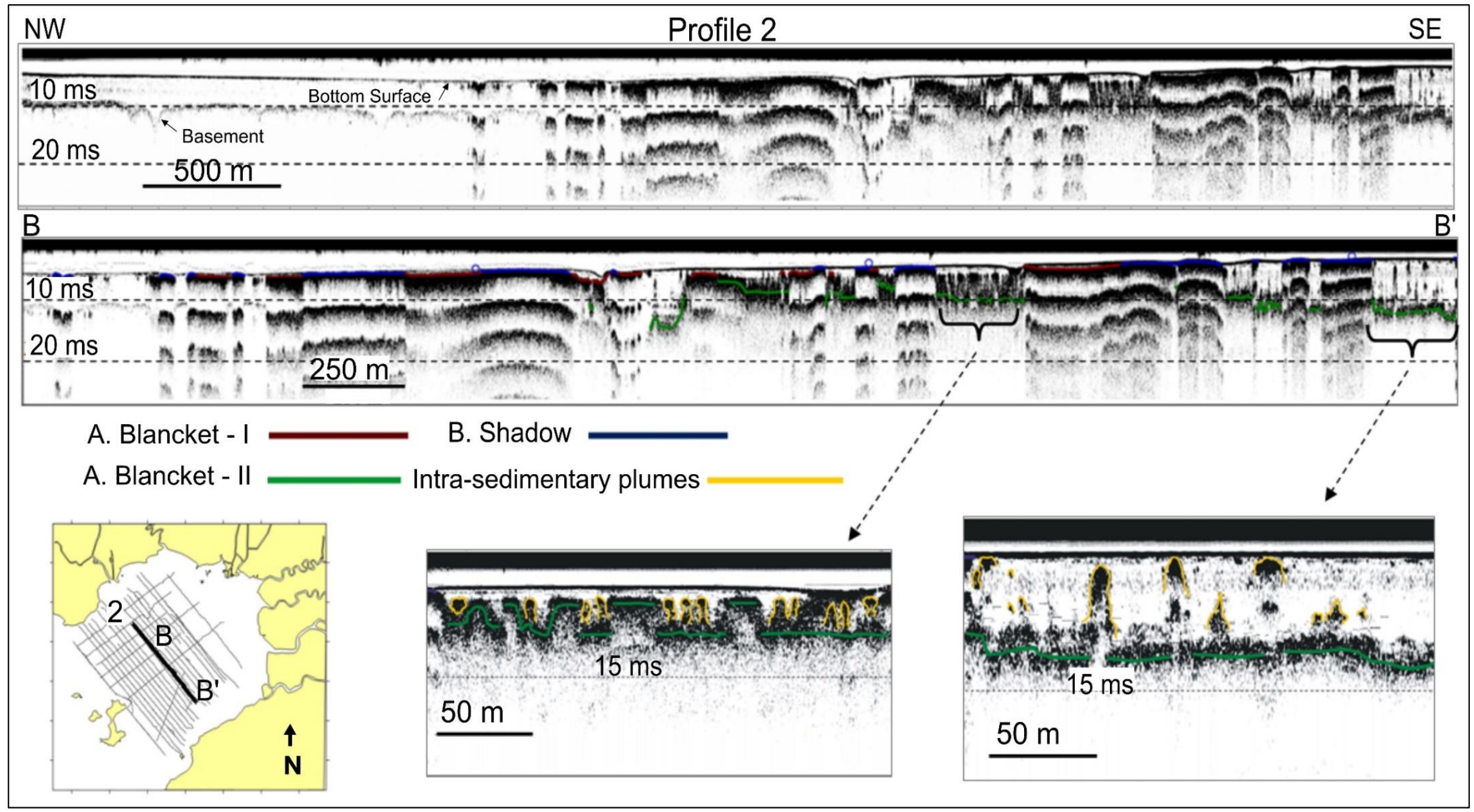

Fig. 10. Profile 2 displays percolation of gas within the sediments. 
Contrary to expectations, since the gas has resistive properties, the profiles with the highest values of resistivity were found in the gas free sediments $(0.54$ to $1.98 \Omega \cdot \mathrm{m})$. These findings may be related to the presence of high percentage of clay in the gas charged sediments. According to Becegato and Ferreira (2005), clays have the property to facilitate the passage of electrical current due to the increased amount of interstitial fluid.

\subsection{The benthic foraminiferal response to TOC enrichment and gas release}

Living benthic foraminiferal assemblages of the NE sector of the Guanabara Bay include species that have been reported in other works previously performed in this ecosystem (e.g. Kfouri-Cardoso et al., 2006; Laut et al., 2012; Pereira et al., 2006; Figueira et al., 2007; Vilela et al., 2001 a, b, 2003, 2004, 2007, 2011; Donnici et al., 2012; Eichler et al., 2013; Clemente et al., 2015; Baptista Neto et al., 2016) as well as in other Brazilian (e.g., Brönnimann et al., 1981; Bonetti and Eichler, 1997; Raposo et al., 2016), and worldwide (Murray, 1991, 2006; Laut et al., 2014, 2016 a; b, c; Martins et al., 2015 a, b, 2016 a, b) transitional coastal environments. Laut et al. (2012b) based on published works gave an overview of the main species that occur in the Guanabara Bay.

Living benthic foraminiferal assemblages of the studied area include species that can tolerate changes in physicochemical parameters such as temperature, salinity, $\mathrm{pH}$ and oxygen, which change seasonally depending on the season and meteorological conditions and daily depending on tidal phases. They show, in general, a reduced density and diversity and are largely dominated by $A$. tepida and locally by C. excavatum.

However, some variability was observed depending on some abiotic variables as suggested by the PCA (Fig. 7). These statistical results indicate that living benthic foraminifera diversity (indicated by $\mathrm{S}$ and $\mathrm{H}^{\prime}$ ) and equitability (J') and some species, such as B. striatula, G. praegeri, D. parkeri, E. gerthi, B. compacta and R. floridana are negatively correlated to TOC, S1, S2 and S3 but positively correlated with $\delta^{13} \mathrm{C}$ and OI values. This group of species reaches the highest relative abundance in the stations located nearest the Guanabara Bay entrance and in waters with relatively high salinity. All these relationships indicate that this group of species is sensitive to an excessive increase of organic matter, prefer high quality of $\mathrm{OM}$ and are favored by aerated waters with mainly marine salinity.
Ammonia tepida, B. elegantissima and FD are positively correlated with PI suggesting their probably tolerance to contamination by oil and to the exhalation of gas from the sediments. In particular, $A$. tepida has been recognized to be one of the most tolerant species to pollution (e.g., Frontalini and Coccioni, 2008; Romano et al., 2009; Armynot du Châtelet et al., 2011; Foster et al., 2012).

All the other species have negative or weak correlations with PI. In opposition to the increase of PI there are $C$. excavatum and $A$. salsum. Both $C$. excavatum and $A$. salsum are detritivorous species (Boltovskoy, 1965; Murray, 1991, 2006). Results of this work indicate that both species, which are also known to be tolerant to large environmental variability caused for instance by oscillation of temperature, salinity and oxygen content (Murray, 1991, 2006), are probably sensitive to organic matter contaminated by oil.

\section{Conclusion}

Results of this work evidence that significant accumulation of gas occurs in the NE part of the Guanabara Bay. The main drainage that flows into the bay and the currents circulation pattern favor the occurrence of high sediment accumulation rates and the deposition of fine grained sediments enriched in organic matter. Geochemical data suggest that organic matter present in surface sediments can potentially generate gas.

The highest TOC content results in a higher source generation potential and free hydrocarbon content and can give place to a higher production of $\mathrm{CO}_{2}$ from organic matter degradation.

Geophysical results allowed the identification of high concentration of shallow gas from the water-sediment interface until $9 \mathrm{~m}$ below this interface. These occurrences of shallow gas are related to the migration from the lower layers, possibly related to the capping of those layers by Holocene muds, and a recent gas generation in near-surface sediments is also possible by favorable conditions (high OM content, high sedimentation rate and fine grained sediment); gas escape to the water column are occurring in several places of the NE sector of the Guanabara Bay.

The impact on benthic organisms of the high accumulation of organic matter and releasing of gas from the sediment is yet not well known in the Guanabara Bay. However, the living assemblages of benthic foraminifera are characterized in general by low density, diversity and equitability and high dominance, which are indicative of high environmental stress. In the stations affected by the highest accumulation of organic matter, located in zones where gas 
seeping takes place, foraminiferal assembles displayed the lowest density, diversity and equitability. Foraminiferal density is slightly higher where TOC content decreases but the quality of organic matter increases due to a relatively high supply of materials resultant of autochthonous biological productivity and smaller deposition of organic materials provided from continental sources.

Thus, it can be speculated that the excessive accumulation of degraded organic matter (low food quality and generation of redox conditions) and the gas escape represent adverse factors for benthic communities. Some foraminiferal species however seems to have a higher tolerance to these adverse environments. Ammonia tepida seems to be the most tolerant species to stress caused by reducing conditions, high amount of organic matter with low quality and gas seeping.

\section{Acknowledgment}

The authors would like to thank the Fundação de Amparo à Pesquisa do Estado do Rio de Janeiro - FAPERJ by partial financial support of LGQM-UERJ, and for the Scientific Initiation Fellowship of Maria Clara Machado da Fonseca. The authors would like to thank Mr. Nelson José Marques and Mr. Marcos Gonçalves, of LGQM-UERJ, and to Darlly Reis for technical support. Seismic data and cores collection also was possible through financial support from FAPERJ, Edital 21, 2012, Apoio às Instituições de Ensino e Pesquisa Sediadas no Estado do Rio de Janeiro. Processo no. E-26/112.051/2012.

\section{References}

Amador, E. S., 1992. Baía de Guanabara: um balanço histórico. In: Abreu, M.A. (Org.). Natureza e sociedade no Rio de Janeiro. Rio de Janeiro: Biblioteca Carioca, p. 201-258.

Amador, E.S., 1980a. Unidades sedimentares Cenozóicas do Recôncavo da Baía de Guanabara. (Folhas Petrópolis E Itaboraî). Anais da Academia Brasileira de Ciencias 52 (4), 743-761.

Amador, E.S., 1980b. Assoreamento da Baía de Guanabara Taxas de Sedimentação. Anais da Academia Brasileira de Ciencias 52 (4), 723-742.

Armynot du Châtelet, E.A., du Chatelet, E.A., Gebhardt, K., Langer, M.R., 2011. Coastal pollution monitoring: Foraminifera as tracers of environmental perturbation in the port of Boulogne-sur-Mer (northern France). Neues Jahrbuch für Geologie und Paläontologie. Abhandlungen 262, 91-116. doi: 10.1127/0077-7749/2011/0187

Angulo, R.J., Souza, M.C., Reimer, P.J., Sasaoka, S.K., 2005. Reservoir effect of the southern and southeastern Brazilian coast. Radiocarbon 47 (1), 67-73. doi.org/10.2458/azu_js_rc.47.2801
Ayres Neto, A., 1998. Relationships between physical properties and sedimentological parameters of near surface marine sediments and their applicability in the solution of engineering and environmental problems. $\mathrm{PhD}$ thesis, University of Kiel, Germany, 126 p.

Baltzer, A., Tessier, B., Nouzé, H., Bates, R., Moore, C., Menier, D., 2005. Seistec Seismic Profiles: a Toll to Differentiate Gas Signatures. Marine Geophysical Researches 26 (2-4), 235-245. doi:10.1007/s11001-005-3721-x

Baptista Neto, J.A., Barreto, C.F., Vilela, C.G., Fonseca, E.M., Melo, G.V., Barth, O.M., 2016. Environmental change in Guanabara Bay, SE Brazil, based in microfaunal, pollen and geochemical proxies in sedimentary cores. Ocean \& Coastal Management. In Press, doi.org/10.1016/j.ocecoaman.2016.04.010

Baptista Neto, J.A., Smith, B.J., MCalister, J.J., 2000. Heavy metal concentrations in surface sediments in a nearshore environment, Jurujuba Sound, SE Brazil. Environmental Pollution, 109 (1), 1-9. doi.org/10.1016/S02697491(99)00233-X

Becegato, V.A., Ferreira, F.J.F., 2005. Gama espectrometria, resistividade elétrica e susceptibilidade magnética de solos agrícolas no noroeste do estado de Paraná. Revista Brasileira de Geofísica 23, 371-406.

Boltovskoy, E., Giussani, G., Watanabe, S., Wright, R., 1980. Atlas of Benthic Shelf Foraminifera of the Southwest Atlantic. Dr. W. Junk bv Publishers, The Hague-Boston-London, p.147.

Boltovskoy, E., 1965. Los foraminiferos recientes. Eudeba, Buenos Aires, p 510.

Bonetti, C., Eichler, B.B., 1997. Benthic foraminifers and thecamoebians as indicators of River-Sea gradients in the estuarine zone of Itapitangui River, Cananéia (SP, Brazil). Anais da Academia Brasileira de Ciências 69, 545-563.

Bronk Ramsey, C., 2009. Bayesian analysis of radiocarbon dates. $\begin{array}{llll}\text { Radiocarbon } & 51 & \text { (1), }\end{array}$ doi.org/10.2458/azu_js_rc.51.3494

Brönnimann, P., Moura, J.A., Dias-Brito, D., 1981. Estudos Ecológicos na Baía de Sepetiba, Rio de Janeiro, Brasil: Foraminíferos. In: Congresso Latino-Americano de Paleontologia, Porto Alegre, RS, 75-861.

Carreira, R.S., Wagener A.L.R., Readman, J.W., Fileman, T.W., Macko, S.A., Veiga, A., 2002. Changes in the sedimentary organic carbon pool of a fertilized tropical estuary, Guanabara Bay, Brazil: an elemental, isotopic and molecular marker approach. Marine Chemistry 79, 207-227. doi.org/10.1016/S0304-4203(02)00065-8

Catanzaro, L.F., Baptista Neto, J.A., Guimarães, M.S.D., Silva, C.G., 2004. Distinctive sedimentary processes in Guanabara Bay - SE/Brazil, based on the analysis of echo-character (7.0 $\mathrm{kHz})$. Revista Brasileira de Geofísica 22(1), 69-83. doi.org/10.1590/S0102-261X2004000100006 
Clemente, I.M.M.M., Silva, F.S., Laut, L.L.M., Frontalini, F., Costa, V.L., Rodrigues, M.A.C., Pereira, E., Bergamaschi, S., Filho, J.G.M., Martins, M.V.A., 2015. Biochemical Composition and Foraminiferal Content of Sediments for Determining Bottom Sector Environments in Guanabara Bay (Rio de Janeiro, Brazil). Journal of Coastal Research, 315, 1190-1204. doi.org/10.2112/JCOASTRES-D-14-00104.1

Cushman J.A., Brönnimann P., 1948a. Some new genera and species of foraminifera from brackish water of Trinidad. Cushman Laboratory of Foraminiferal Research Contributions 24, 15-21.

Cushman J.A., Brönnimann P., 1948b. Additional new species of arenaceous foraminifera from shallow waters of Trinidad. Cushman Laboratory of Foraminiferal Research Contributions 24, 37-42.

Debenay, J.-P., Geslin, E., Eichler, B.B., Duleba, W., Sylvestre, F., Eichler, P., 2001. Foraminiferal Assemblages in a Hypersaline Lagoon, Araruama (R.J.) Brazil. Journal of Foraminiferal Research 31, 133 - 155, 2001. doi: 10.2113/0310133

Debenay, J.-P., Eichler, B. B., Duleba, W., Bonetti, C., EichlerCoelho, P., 1998. Water stratification in coastal lagoons: its influence on foraminiferal assemblages in two Brazilian lagoons. Marine Micropaleontology, 35, 67-89. doi.org/10.1016/S0377-8398(98)00011-5

Delavy, F.P., 2015. Assinaturas acústicas e propriedades físicas dos sedimentos carregados de gás na porção $\mathrm{NE}$ da Baía de Guanabara - RJ. Dissertação (Mestrado em Geologia e Geofísica Marinha) - Universidade Federal Fluminense, Niterói, 91 p.

Donnici, S., Serandrei-Barbero, R., Bonardi, M., Sperle, M., 2012. Benthic foraminifera as proxies of pollution: The case of Guanabara Bay (Brazil). Marine Pollution Bulletin 64 (10), 2015-2028. doi.org/10.1016/j.marpolbul.2012.06.024

Eichler, P.P.B., Eichler, B.B., Miranda, L.B., Pereira, E.R.M., Kfouri, P.B.P., Pimenta, F.M., Bérgamo, A.L., Vilela, C.G., 2003. Benthic foraminiferal response to variations in temprature, salitity, dissolved oxygene and organic carbon, in the Guanabara Bay, Rio de Janeiro, Brasil. Anuário do Instituto de Geociências - UFRJ, 26, 36-51.

El Nady, M.M., Ramadan, F.S., Hammad, M.M., Lotfy, N.M., 2015. Evaluation of organic matters, hydrocarbon potential and thermal maturity of source rocks based on geochemical and statistical methods: Case study of source rocks in Ras Gharib oilfield, central Gulf of Suez, Egypt. Egyptian Journal of Petroleum 24, 203-211. doi.org/10.1016/j.ejpe.2015.05.012

Espitalié, J., Deroo, G., Marquis, F., 1985/86. La pyrolyse RockEval et ses applications. Deuxieme partie. Revue de l'Institut Francais du Petrole 40, 563-579, 775-784, 41, 73-89.

Espitalié, J., Madec M. and Tissot B., 1980. Role of mineral matrix in kerogen pyrolysis: influence on petroleum generation and migration. Bulletin American Association Petrology Geology 64, 59-66.
Espitalié, J., Laporte, J.L., Madec, M., Marquis, F., Leplat, P., Paulet, J., Boutefeu, A., 1977. Methode rapide de caracterisation des roches meres, de leur potential petrolier et de leur degre d'evolution. Revue de l'Institut Francais du Petrole 32, 23-42.

Figueira, B.O., Vilela, C.G., Baptista Neto, J.A., 2007. Anthropogenic Pollution Evaluation Using Patterns of Distribution of Foraminiferal Species from Cores of Guanabara Bay, RJ. Anuário do Instituto de GeocienciasUFRJ 30 (1), 145-157.

Figueiredo Jr., A.G., Toledo, M.B., Cordeiro, R.C., Godoy, J.M.O., Silva, F.T., Vasconcelos, S.C., Santos, R.A., 2014. Linked variations in sediment accumulation rates and sea-level in Guanabara Bay, Brazil, over the last 6000 years. Paleogeography, Paleoclimatology, Paleoecology 415, 83-90. http://dx.doi.org/10.1016/j.palaeo.2014.08.027

Folk, R.L., Ward, W.C., 1957. Brazos River bar: a study in the significance of grain size parameters. Journal of Sedimentology and Petrology 27 (1), 3-27.

Fontana, L.F., Laut, L.L.M., Figueiredo Jr, A.G., Crapez, M.A.C., Rosa, T.D.L., 2006. Foraminifera and bacterial activity in oil spill impacted mangrove, Guanabara Bay, Brazil. Anuário do Instituto de Geociencias-UFRJ 29(1), 415-416.

Foster, W.J., Armynot du Châtelet, E., Rogerson, M., 2012. Testing benthic foraminiferal distributions as a contemporary quantitative approach to biomonitoring estuarine heavy metal pollution. Marine Pollution Bulletin 64, 1039-1048. doi:10.1016/j.marpolbul.2012.01.021

Frontalini, F., Coccioni, R., 2008. Benthic foraminifera for heavy metal pollution monitoring: a case study from the central Adriatic Sea coast of Italy. Estuarine, Coastal and Shelf Science 76, 404-417. doi.org/10.1016/j.ecss.2007.07.024

Galvão, A., 2014. Distribuição superficial de sedimentos e arranjo sismoestratigráfico, NE da Baía de Guanabara. MsD thesis (Mestrado em Geologia e Geofísica Marinha), Universidade Federal Fluminense, Niterói, 117 p.

Garcia-Gil, S., Vilas, F., Garcia-Garcia, A., 2002. Shallow gas features in incised-valley fills (Ría de Vigo, NW Spain): a case study. Continental Shelf Research 22, 2303-2315, doi.org/10.1016/S0278-4343(02)00057-2

Guimarães, M.S.D., Catanzaro, L.F., Baptista Neto, J.A., Vilela, C. G., Brehme, I., 2007. Caracterização Textural dos Sedimentos Superficiais de Fundo e Dinâmica Sedimentar na Baía de Guanabara, Rio de Janeiro. Revista Tamoios 2, 1-32.

Hamilton, E.L., 1972. Compressional-wave attenuation in marine sediments. Geophysics, 37(4), 620-646.

Hovland, M., Judd, A.G., Burke Jr., R.A., 1993. The global flux of methane from shallow submarine sediments. Chemosphere26, 1-4, 559-578. doi:10.1016/0045-6535(93)90442-8.

Hovland, M., Judd, A.G., 1988. Seabed Pockmarks and Seepages: Impact on Geology, Biology, and Marine Environment, Graham and Trotman, London, 293 pp. 
Iglesias, J., García-Gil, S. 2007. High-resolution mapping of shallow gas accumulations and gas seeps in San Simón Bay (Ría de Vigo, NW Spain). Some quantitative data. Geo-Marine Letters, 27 (2), 103-114. http://dx.doi:10.1007/s00367-0070065-3

Ivanov, M.K., Limonov, A.F., Woodside, J.M., 1998. Extensive deep fluid flux through the sea floor on the Crimean continental margin (Black Sea), Geological Society, London, Special Publications 137 (1), 195-213. http://dx.DOI: 10.1144/GSL.SP.1998.137.01.16.

JICA, 1994. The Study on Recuperation of the Guanabara Bay Ecosystem. Japan International Cooperation Agency 8 volumes.

Judd, A.G., 2004. Natural seabed gas seeps as sources of atmospheric methane. Environmental Geology 46, 988-996. http://dx.DOI: 10.1007/s00254-004-1083-3

Judd, A.G., Hovland, M. Dimitrov, L.I., Garcia-Gill, S., Jukes, V., 2002. The geological methane budget at Continental Margins and its influence on climate change. Geofluids 2 (2), 109-126. http://dx.DOI: 10.1046/j.1468-8123.2002.00027.x.

Judd, A., Davies, G., Wilson, J., Holmes, R., Baron, G., Bryden, I., 1997. Contributions to atmospheric methane by natural seepages on the UK continental Shelf. Marine Geology 137, 165-189. http://dx.doi:10.1016/S0025-3227(96)00087-4

Kfouri-Cardoso, P.B.P., Simões, M.G., Rodrigues, S.C., Eichler, B.B., Sousa, S.H.M., Eichler, P.B., Figueira, R.C.L., 2006. Taphonomy of benthic foraminiferal tests from the Jurujuba Sound, Guanabara Bay, Rio de Janeiro, Brazil. Anuário do Instituto de Geociencias-UFRJ 29 (1), 546-547.

Kitidis, V., Tizzard, L., Uher, G., Judd, A., Upstill-Goddard, R.C., Head, I.M., Gray, N.D. Taylor, G., Durán, R., Diez, R., Igesias, J., García-Gil, S., 2007. The biogeochemical cycling o methane in Ría de Vigo, NW Spain: Sediment processing and sea-air exchange. Journal of Marine Systems 66, 258-271. http://dx.doi.org/10.1016/j.jmarsys.2006.03.022

Kjerfve, B., Ribeiro, C.H.A., Dias, G.T.M., Filippo, A.M., Quaresma, V.S., 1997. Oceanographic characteristics of an impacted coastal bay: Baía de Guanabara, Rio de Janeiro, Brazil. Continental Shelf Research 17 (13), 1609-1643. http://dx.doi:10.1016/S0278-4343(97)00028-9

Laut, L.L.M., Martins, M.V.A., Frontalini, F., Belart, P., Santos, V.F., Lorini, M.L., Fortes, R.R., Silva, F.S., Vieira, S.S.S., SouzaFilho, P.W.M., 2016a. Biotic (foraminifera and thecamoebians) and abiotic parameters as proxies for indicationof the environmental heterogeneity in Caeté River Estuary, Amazon Coast, Brazil. Journal of Sedimentary Environments 1(1), 1-16. http://dx.doi: 10.12957/jse.2016.21264

Laut, L.L.M., Clemente, I.M.M.M., Belart, P., Martins, M.V.A., Frontalini, F., Laut, V.M., Gomes, A., Boski, T., Lorini, M.L., Fortes, R.R., Rodrigues, M.A.C., 2016 b. Multiproxies (benthic foraminifera, ostracods and biopolymers) approach applied to identify the environmental partitioning of the Guadiana River Estuary (Iberian Peninsula). Journal of Sedimentary
Environments 1(2), 184-201. http://dx.doi: $10.12957 /$ jse. 2016.22534

Laut, L.L.M., Martins, V., Silva, F.S., Crapez, M.A.C., Fontana, L.F., Carvalhal-Gomes, S.B.V., Souza, R.C.C.L., 2016 c. Foraminifera, Thecamoebians, and Bacterial Activity in Polluted Intertropical and Subtropical Brazilian Estuarine Systems. Journal of Coastal Research 32 (1), 56-69. http://dx.Doi:10.2112/JCOASTRES-D-14-00042.

Laut, L.L.M., Cabral, I.A., Rodrigues, M.A.C., Silva, F.S., Martins, M.V.A., Boski, T., Gomes, A.I., Alverinho Dias, J.M., Fontana, L.F., Laut, V.M., Mendonça-Filho, J.G., 2014. Compartimentos ambientais do Estuário do Rio Arade, Sul de Portugal, com base na distribuição e ecologia de foraminíferos. Anuário do Instituto de Geociências-UFRJ 37 (2), 60-74. http://dx.doi.org/10.11137/2014_2_60_74

Laut, L.L.M., Silva, F.S., Martins, V., Rodrigues, M.A.C., Mendonça, J.O., Clemente, I.M.M.M., Laut, V.M., Mentzigen, L.G., 2012a. Foraminíferos do Complexo Sepetiba/Guaratiba. In: Rodrigues, M.A.C., Pereira, S.D. and Santos, S.B. (eds.). Baía de Sepetiba, estado da arte. Editora Corbã, p.115-148.

Laut, L.L.M., Laut, V.M., 2012b. Bactéria, diatomácias e foraminíferos do sediment.In: Meniconi. M.F.G., Silva, T.A., Fonseca, M.L., Lima, S.O.F., Lima, E.F.A., Lavrado, H.P., Figueiredo Jr., A.G. (Eds.) Baia de Guanabara, Sintese do Conhecimento Ambiental. Biodiversidade. Volume II, Petrobras, Rio de Janeiro, p. 271-291.

Loeblich, A.R., Tappan, H., 1988. Foraminiferal Genera and their Classification. Van Nostrand Reinhold Company, New York. 970 pp.

Lowe, J.J., Walker, M.J.C., 1997. Reconstructing Quaternary Environments, Longman Publ., London, 446 pp.

Martins, M.V.A., Helali, M.A., Zaaboub, N., Boukef-BenOmrane, I., Frontalini, F., Reis, D., Portela, H Clemente, I.M.M.M., Nogueira, L., Pereira, E., Miranda, P., El Bour, M., Aleya, L., 2016a. Organic matter quantity and quality, metals availability and foraminifera assemblages as environmental proxy applied to the Bizerte Lagoon (Tunisia). Marine Pollution Bulletin 105, 161-179, http://dx.doi.org/10.1016/j.marpolbul.2016.02.032.

Martins, M.V.A., Pinto, A.F.S., Nogueira, L., Machado, M.C., Laut, L.L.M., Fabrizio Frontalini, F., Zaaboub, N., Rodrigues, M.A.C., Rocha, F., 2016b.Can benthic foraminifera be used as bio-indicators of pollution in areas with a wide range of physiochemical variability?. Estuarine, Coastal and Shelf Science. 182, Part A, 211-225. doi.org/10.1016/j.ecss.2016.10.011

Martins, M.V.A. Zaaboub, N., Aleya, L., Frontalini, F., Pareira, E., Miranda, P., Mane, M., Rocha, F., Laut, L., El Bour, M. 2015a. Environmental quality assessment of Bizerte Lagoon (Tunisia) using living foraminifera assemblages and a multiproxy approach. PLoS ONE. doi.10.1371/journal.pone.0137250

Martins, V.A., Silva, F., Lazaro, L.M.L., Frontalini, F., Clemente, I.M., Miranda, P., Figueira, R., Sousa, S.H.M., Dias, J.M.A., 2015b. Response of benthic foraminifera to organic matter 
quantity and quality and bioavailable concentrations of metals in Aveiro Lagoon (Portugal). PLoS ONE 10 (2), e0118077. http://dx.doi:10.1371/journal.pone.0118077

Martins, V., Gomes, V., 2004. Foraminíferos da margem continental NW Ibérica: sistemática e ecologia. Portugal, Ed. Gomes, 377 p.

Mendonça Filho, J.G., Menezes, T.R., Oliveira, A., Iemma, M.B., 2003. Geomicrobiologia e composição bioquímica de dois testemunhos da Enseada de Jurujuba - Baía de Guanabara - SE Brasil. Anuário do Instituto de Geociencias-UFRJ 26, 69-78.

Meyers, P.A., 1994. Preservation of elemental and isotopic source identification of sedimentary organic matter. Chemistry Geology 114, 289-302. http://dx.doi:10.1016/00092541(94)90059-0

Missiaen, T., Murphy, S., Loncke, L., Henriet J.P., 2002. Very highresolution seismic mapping of shallow gas in the Belgian coastal zone. Continental Shelf Research 22 (16), 2291-2301. http://dx.DOI: 10.1016/S0278-4343(02)00056-0.

Monteiro, F.F., Cordeiro, R.C., Santelli, R.E., Machado, W., Evangelista, H., Villar, L.S., Viana, L.C.A., Bidone, E.D., 2012. Sedimentary geochemical record of historical anthropogenic activities affecting Guanabara Bay (Brazil) environmental quality. Environmental Earth Sciences 65, 1661-1669. http://dx.DOI: 10.1007/s12665-011-1143-4

Murray, J.W., 2006. Ecology and applications of benthic foraminifera, Cambridge, UK, Cambridge University Press, 426p.

Murray, J.W., 1991. Ecology and Palaeoecology of Benthic Foraminifera New York: Longman Scientific and Technical 402p.

Okyar, M., Ediger, V., 1999. Seismic evidence of shallow gas in the sediment on the shelf off Trabzon, southeastern Black Sea. Continental Shelf Research 19, 575-587.

Overpeck, J.T., Cole, J.E., 2006. Abrupt change in Earth's climate system. Annual Review of Environment and Resources 31, 131. doi: 10.1146/annurev.energy.30.050504.144308.

Pereira, E.R.M., Eichler, P.P.B, Eichler B.B., 2006. Foraminifera as proxies in environmental diagnostic in Guanabara Bay, RJ. Journal of Coastal Research 39 (SI), 1395-1398.

Peters, K.E., Cassa, M.R., 1994. Applied source rock geochemistry. In: Magoon, L.B., Dow, W.G. (eds.), The Petroleum System from Source to Trap. American Association of Petroleum Geologists Memoir 60, 93-120.

Peters, K.E., 1986. Guidelines for evaluating petroleum source using programmed pyrolysis. Bulletin American Association of Petroleum Geologists 70, 318-329.

Quaresma, V.S., Dias, G.T.M., Baptista-Neto, J.A., 2000. Caracterização de padrões de sonar de varredura lateral e 3,5 e $7,0 \mathrm{kHz}$ na porção sul da Baía de Guanabara - RJ. Revista
Brasileira de Geofísica18 (2), 201-214. doi.org/10.1590/S0102261X2000000200008.

Quaresma, V.S., 1997. Caracterização da dinâmica sedimentar da Baía de Guanabara, RJ. Dissertação de Mestrado - LAGEMAR - UFF, Niterói, 97pp.

Raposo, D., Laut, V., Clemente, I., Virgínia, M., Fabrizio, F., Silva, F., Lorini, M.L., Rafael, F., Laut, L., 2016. Recent benthic foraminifera from the Itaipu Lagoon, Rio de Janeiro (southeastern Brazil). Check List (São Paulo. Online), 12 (1959), 14 p. doi.org/10.15560/12.5.1959

Reimer, P.J., Bard, E., Bayliss, A., Beck, J.W., Blackwell, P.G., Bronk Ramsey, C., Grootes, P.M., Guilderson, T.P., Haflidason, H., Hajdas, I., Hatté, C., Heaton, T.J., Hoffmann, D.L., Hogg, A.G., Hughen, K.A., Kaiser, K.F., Kromer, B., Manning, S.W., Niu, M., Reimer, R.W., Richards, D.A., Scott, E.M., Southon, J.R., Staff, R.A., Turney, C.S.M., Van Der Plicht, J., 2013. IntCal13 and Marine13 radiocarbon age calibration curves 0-50,000 years cal BP. Radiocarbon, 55 (4), 1869-87. doi: 10.2458/azu_js_rc.55.16947

Romano, E., Bergamin, L., Ausili, A., Pierfranceschi, G., Maggi, C., Sesta, G., Gabellini, M., 2009. The impact of the Bagnoli industrial site (Naples, Italy) on sea-bottom environment. Chemical and textural features of sediments and the related response of benthic foraminifera. Marine Pollution Bulletin 59, 245-256. doi.org/10.1016/j.marpolbul.2009.09.017

Santos Neto, E.V., 2004. Geoquímica de gases: uma nova tecnologia em avaliação de sistemas petrolíferos. Boletim de Geociências, Petrobras, Rio de Janeiro, 12 (2), 357-383.

Schoell, M., 1988. Multiple origins of methane in the Earth. Chemical Geology 71 (1-3), 1-10. doi: 10.1016/00092541(88)90101-5.

Schönfeld, J., Alve, E., Geslin, E., Jorissen, F., Korsun, S., Spezzaferri, S. and members of the FOBIMO group, 2012. The FOBIMO (FOraminiferal BIo-MOnitoring) initiative Towards a standardised protocol for soft-bottom benthic foraminiferal monitoring studies. Marine Micropaleontology 94-95, 1-13. doi.org/10.1016/j.marmicro.2012.06.001

Schubert, C., Calvert, S., 2001. Nitrogen and carbon isotopic composition of marine and terrestrial organic matter in Arctic Ocean sediments: implications for nutrient utilization and organic matter composition. Deep Sea Res., Part I, 48, 789-810. doi.org/10.1016/S0967-0637(00)00069-8

Silva, F.S., Pereira, D.C., Nuñez, L.S., Krepsk, N., Fontana, L.F., Baptista Neto, J.A., Crapez, M.A.C., 2008. Bacteriological Study of the Superficial Sediments of Guanabara Bay, RJ, Brazil. Brazilian Journal of Oceanography 56 (1), 13-22. doi.org/10.1590/S1679-87592008000100002

Taylor, D.I., 1992. Nearshore shallow gas around the U.K. coast. Continental Shelf Research 12 (10), 1135-1144.

van Krevelen, D.W., 1950. Graphical-statistical method for the study of structure and reaction processes of coal. Fuel 29, 269-84. 
Vardar, D., Alpar, B., 2016. High-Resolution Seismic characterization of shallow gas accumulations in the southern Shelf of Marmara Sea, Turkey. Acta Geophysica 64 (3), 589609. doi: 10.1515/acgeo-2015-0059

Vilela, C.G., Batista, D.S., Baptista Neto, J.A., Ghiselli, R.O., 2011. Benthic foraminifera distribution in a tourist lagoon in Rio de Janeiro, Brazil: A response to anthropogenic impacts. Marine Pollution Bulletin 62, 2055-2074. doi.org/10.1016/j.marpolbul.2011.07.023

Vilela, C.G., Figueira, B.O., Baptista Neto, J.A., 2007. Ecologia e Paleocologia na Baía de Guanabara, Rio de Janeiro, Durante os Últimos 6000 anos, com Base em Variações na Assembléia de Foraminíferos Bentônicos. Paleontologia: Cenários da Vida. Editora Interciência 2, 345-361.

Vilela, C.G., Batista, D.S., Baptista-Neto, J.A., Crapez, M., Mcallister, J.J., 2004. Benthic foraminifera distribution in high polluted sediments from Niterói Harbor (Guanabara Bay), Rio de Janeiro, Brazil. Anais da Academia Brasileira de Ciências 76, 161-171.

Vilela, C.G., Sanjinpes, A.E.S., Ghiselli Jr., R.O., Mendonça-Filho, J.G., Baptista Neto, J.A., Barbosa, C.F., 2003. Seach for bioindicators of pollution in the Guanabara Bay: integrations of ecologic patterns. Anuário do Instituto de Geociências UFRJ 26, 25-35.
Vilela, C.G., Baptista Neto, J.A., Mendonça Filho, J.G., Barbosa, C.F., Sanjinés, A.E.S., Pugirá, M. da S., Iemma, M.B., 2001a. Distribuição de foraminíferos em subambientes da Baía de Guanabara. VIII Congresso da Associação Brasileira de Estudos Quaternários ABEQUA, Mariluz - Imbé-RS, p. 418-419.

Vilela, C.G., Baptista Neto, J.A., Crapez, M.A.C., Batista, D.S., 2001b. Avaliação de foraminíferos bentônicos e metais pesados em sedimentos poluídos em Niterói - RJ. VIII Congresso da Associação Brasileira de Estudos Quaternários - ABEQUA, Mariluz - Imbé-RS, p. 423424.

Yun, J.W., Orange, D.L., Field, M.E., 1999. Subsurface gas offshore of northernDistribution, morphology, and formation of pockmarks in Lake Constance, Germany. Marine Geology 154, 1-4, 357-368. doi: 10.1016/S00253227(98)00123-6.

Wessels, M., Bussmann, I., Schloemer, S., Schlüter, M., Böder, V., 2010. California and its link to submarine geomorphology. Limnology and Oceanography 55(6), 2010, 2623-2633. doi:10.4319/1o.2010.55.6.2623 
Appendix 1. Biotic data. Ecological parameters and percentage of living benthic foraminifera species per sample. $\mathrm{N}$ - number of living specimens identified and counted in each sample; S specific richness; H' - Shannon index; J' - equitability; FD - Foraminifera density (n. $\left.{ }^{\circ} / \mathrm{g}\right)$

\begin{tabular}{|c|c|c|c|c|c|c|c|c|c|}
\hline Percentage of Species in each Station & GB1 & GB2 & GB3 & GB4 & GB5 & GB6 & GB7 & GB8 & GB9 \\
\hline $\mathbf{N}$ & 1041 & 761 & 607 & 345 & 635 & 641 & 945 & 1 & 349 \\
\hline $\mathbf{S}$ & 22 & 11 & 18 & 6 & 10 & 26 & 30 & 1 & 8 \\
\hline $\mathrm{J}^{\prime}$ & 0.28 & 0.27 & 0.35 & 0.14 & 0.34 & 0.42 & 0.52 & nd & 0.57 \\
\hline $\mathbf{H}^{\prime}$ & 0.88 & 0.64 & 1.01 & 0.25 & 0.78 & 1.37 & 1.75 & nd & 1.19 \\
\hline FD & 302 & 213 & 49 & 42 & 3487 & 129 & 625 & 0 & 10 \\
\hline Ammonia parkinsoniana (d' Orbigny, 1839) & 0.0 & 0.0 & 0.0 & 0.3 & 0.0 & 0.3 & 0.0 & nd & 0.0 \\
\hline Ammonia tepida (Cushman, 1926) & 80.2 & 87.0 & 75.8 & 95.1 & 81.4 & 67.9 & 57.6 & nd & 48.4 \\
\hline Ammotium salsum (Cushman \& Brönnimann, 1948) & 0.2 & 0.0 & 0.0 & 0.0 & 0.0 & 0.0 & 0.8 & nd & 15.2 \\
\hline Asterigerinata mamilla (Williamson, 1858) & 0.0 & 0.0 & 0.0 & 0.0 & 0.0 & 0.0 & 0.1 & nd & 0.0 \\
\hline Bolivina compacta Sidebottom, 1905 & 0.2 & 0.0 & 0.0 & 0.0 & 0.0 & 0.6 & 2.5 & nd & 0.0 \\
\hline Bolivina lowmani Phleger \& Parker, 1951 & 0.5 & 1.3 & 0.7 & 0.0 & 0.6 & 0.0 & 0.0 & nd & 0.0 \\
\hline Bolivina striatula Cushman, 1922 & 0.8 & 0.8 & 0.3 & 0.0 & 3.5 & 12.3 & 1.9 & nd & 0.0 \\
\hline Bulimina aculeata d' Orbigny, 1826 & 0.1 & 0.1 & 0.2 & 0.0 & 0.2 & 0.9 & 0.2 & nd & 0.0 \\
\hline Bulimina gibba Fornasini, 1900 & 0.5 & 0.0 & 0.3 & 0.0 & 0.5 & 0.2 & 0.0 & nd & 0.0 \\
\hline Bulimina marginata d' Orbibny, 1826 & 0.0 & 0.0 & 0.0 & 0.0 & 0.0 & 0.0 & 0.1 & nd & 0.0 \\
\hline Buliminella elegantissima (d' Orbigny, 1839) & 8.3 & 2.9 & 8.1 & 0.9 & 5.8 & 2.2 & 4.9 & nd & 0.0 \\
\hline Glocassidulina crassa (d' Orbigny, 1839) & 0.2 & 0.0 & 0.5 & 0.0 & 0.2 & 0.0 & 0.0 & nd & 0.0 \\
\hline Cornuspira involvens (Reuss, 1850) & 0.0 & 0.0 & 0.0 & 0.0 & 0.0 & 0.0 & 0.1 & nd & 0.0 \\
\hline Cribroelphidium excavatum (Terquem, 1875) & 5.4 & 3.5 & 5.1 & 0.3 & 1.7 & 1.7 & 2.1 & nd & 32.1 \\
\hline Cribroelphidium poeyanum (d'Orbigny, 1826) & 0.0 & 0.0 & 0.0 & 0.0 & 0.0 & 0.2 & 0.2 & nd & 0.0 \\
\hline Discorbis parkeri Natland, 1950 & 0.0 & 0.0 & 0.0 & 0.0 & 0.0 & 0.0 & 6.6 & nd & 0.0 \\
\hline Elphidium gerthi van Voorthuysen, 1957 & 1.0 & 0.5 & 0.0 & 0.0 & 0.0 & 2.3 & 4.4 & nd & 0.3 \\
\hline Elphidium gunteri Cole, 1931 & 0.3 & 0.0 & 0.0 & 0.0 & 0.0 & 0.0 & 0.3 & nd & 0.0 \\
\hline Elphidium incertum (Williamson 1858) & 0.2 & 0.0 & 0.0 & 0.0 & 0.0 & 0.0 & 0.0 & nd & 0.0 \\
\hline Fissurina lucida (Williamson, 1848) & 0.0 & 0.0 & 0.0 & 0.0 & 0.0 & 0.5 & 0.2 & nd & 0.0 \\
\hline Fursenkoina conspiqua (Pishvanova, 1960) & 0.0 & 0.0 & 0.2 & 0.0 & 0.0 & 0.0 & 0.0 & nd & 0.3 \\
\hline Fursenkoina pontoni (Cushman, 1932) & 0.0 & 0.0 & 0.0 & 0.0 & 0.0 & 0.0 & 0.0 & nd & 0.3 \\
\hline Gavelinopsis praegeri Heron-Allen and Earland, 1913 & 0.4 & 0.9 & 0.7 & 0.3 & 0.2 & 0.8 & 9.2 & nd & 0.0 \\
\hline Haplophragmoides wilberti Andersen, 1953 & 0.0 & 0.0 & 0.0 & 0.0 & 0.0 & 1.1 & 0.2 & nd & 0.0 \\
\hline Hopkinsina pacifica Cushman, 1933 & 0.3 & 0.0 & 0.2 & 0.0 & 0.0 & 0.2 & 0.3 & nd & 0.9 \\
\hline Lagena striata var. (d'Orbigny, 1839) & 0.0 & 0.0 & 0.2 & 0.0 & 0.0 & 0.0 & 0.1 & nd & 0.0 \\
\hline Lepidodeuterammina ochracea (Williamson, 1858) & 0.3 & 0.4 & 0.5 & 0.0 & 0.0 & 0.2 & 0.1 & nd & 0.0 \\
\hline Miliolinella lutea (d'Orbigny, 1839) & 0.1 & 0.3 & 0.2 & 0.0 & 0.0 & 0.3 & 0.0 & nd & 0.0 \\
\hline
\end{tabular}


Appendix 1 (cont.).Biotic data. Ecological parameters and percentage of living benthic foraminifera species per sample.

\begin{tabular}{|c|c|c|c|c|c|c|c|c|c|}
\hline Percentage of Species in each Station & GB1 & GB2 & GB3 & GB4 & GB5 & GB6 & GB7 & GB8 & GB9 \\
\hline Neoconorbina terquemi (Rzehak, 1888) & 0.0 & 0.0 & 0.0 & 0.0 & 0.0 & 0.5 & 0.0 & nd & 0.0 \\
\hline Nonionella atlantica Cushman, 1936 & 0.0 & 0.0 & 0.0 & 0.0 & 0.0 & 0.0 & 0.1 & nd & 0.0 \\
\hline Ophthalmidium balkwilli Macfadyen, 1939 & 0.1 & 0.0 & 0.0 & 0.0 & 0.0 & 0.0 & 2.1 & nd & 0.0 \\
\hline Pseudoclavulina curta Cushman \& Bronnimann, 1948 & 0.1 & 0.0 & 0.0 & 0.0 & 0.0 & 0.2 & 0.0 & nd & 0.0 \\
\hline Quinqueloculina lamarckiana, s. 1. d'Orbigny, 1839 & 0.0 & 0.0 & 0.0 & 0.0 & 0.0 & 0.2 & 0.0 & nd & 0.0 \\
\hline Quinqueloculina seminula (Linné, 1758) & 0.0 & 0.0 & 0.0 & 0.0 & 0.0 & 0.2 & 0.0 & nd & 0.0 \\
\hline Reophax curtus Cushman, 1920 & 0.0 & 0.0 & 0.0 & 0.0 & 0.0 & 0.0 & 0.5 & nd & 0.0 \\
\hline Reophax nana Rhumbler, 1913 & 0.7 & 2.2 & 6.1 & 3.2 & 6.0 & 3.7 & 3.1 & nd & 2.6 \\
\hline Rosalina bradyi (Cushman, 1915) & 0.0 & 0.0 & 0.2 & 0.0 & 0.0 & 0.2 & 0.1 & nd & 0.0 \\
\hline Rosalina floridana (Cushman, 1922) & 0.0 & 0.0 & 0.0 & 0.0 & 0.0 & 2.5 & 0.4 & nd & 0.0 \\
\hline Rosalina globularis d'Orbigny, 1826 & 0.0 & 0.0 & 0.3 & 0.0 & 0.0 & 0.0 & 0.2 & nd & 0.0 \\
\hline Sagrina primitiva (Cushman, 1920) & 0.0 & 0.0 & 0.0 & 0.0 & 0.0 & 0.0 & 0.2 & nd & 0.0 \\
\hline Siphonina reticulata (Czjzek, 1848) & 0.0 & 0.0 & 0.0 & 0.0 & 0.0 & 0.0 & 0.1 & nd & 0.0 \\
\hline Spirobolivina curta (Cushman, 1923) & 0.0 & 0.0 & 0.0 & 0.0 & 0.0 & 0.3 & 0.0 & nd & 0.0 \\
\hline Textularia earlandi Parker, 1952 & 0.1 & 0.0 & 0.0 & 0.0 & 0.0 & 0.0 & 0.0 & nd & 0.0 \\
\hline Trochammina inflata (Montagu, 1808) & 0.3 & 0.0 & 0.7 & 0.0 & 0.0 & 0.0 & 1.1 & nd & 0.0 \\
\hline
\end{tabular}

